\title{
LEKTORZY JĘZYKA ANGIELSKIEGO W WILNIE I KRAKOWIE W OKRESIE MIĘDZYWOJENNYM. PRÓBA BIOGRAFICZNA*
}

\author{
Mirosława Podhajecka \\ Uniwersytet Opolski
}

\section{ABSTRACT \\ LECTURERS OF ENGLISH IN VILNIUS AND CRACOW BETWEEN THE WARS: BIOGRAPHICAL ATTEMPTS}

This paper concerns lecturers in English at two Polish universities between the wars: the Stefan Batory University in Vilnius and the Jagiellonian University in Cracow. The former employed four teachers of English, while the latter was represented by three. It may be safely assumed that all strived to make English accessible to their fellow countrymen; hence, they contributed in different ways to the EFL market through their didactic endeavours. Their activity was not confined to teaching practices, however, as they had very different career paths. Since little is known of them, this paper offers a closer look at their biographies and embellishes them with archival materials.

Key words: Jagiellonian University, Cracow, Stefan Batory University, Vilnius, lecturers, teaching English.

Słowa kluczowe: Uniwersytet Jagielloński, Kraków, Uniwersytet Stefana Batorego, Wilno, lektorzy, nauczanie angielskiego.

* Pragnę gorąco podziękować osobom, które pomogły mi w trakcie pracy nad artykułem: prof. Tadeuszowi Olejnikowi, prof. Konradowi Studnickiemu-Gizbertowi, Adamowi Podsiadłemu, Hannie Grabińskiej, Eugenii Chmarze, dr. Pawłowi Tribunskiemu i dr. hab. Tomaszowi Pudłockiemu. Dziękuję również pracownikom archiwów: Olivierowi Robertowi, dr. Kennethowi Baxterowi, Julie Greenhill, Clare White, Indze Bumażnikovej, Laurze Molytė, Jessice Borge, Ellen Murphy i Minie Lievijärvi.

Adres do korespondencji: mira.podhajecka@wp.pl 


\section{WSTĘP}

Niniejszy artykuł jest próbą zestawienia biografii lektorów języka angielskiego z dwóch polskich uniwersytetów w okresie międzywojennym: Uniwersytetu Stefana Batorego w Wilnie i Uniwersytetu Jagiellońskiego w Krakowie'. Wybór tematu badawczego może się wydawać mało interesujący, gdyż w hierarchii akademickiej lektorzy zajmowali niską pozycję. Ich nazwiska rzadko pojawiają się w opracowaniach zbiorczych ${ }^{2}$, a ich biogramy - w Polskim Słowniku Biograficznym. Wykonywali oni jednak ważną, pozytywistyczną „pracę u podstaw”, aby poprawić znajomość języków obcych wśród studentów polskich uczelni, mających tworzyć elity II Rzeczypospolitej.

Zgodnie z art. 41 Ustawy o szkołach akademickich z dnia 13 lipca 1920 roku do grona nauczycielskiego uczelni zaliczano pracowników naukowych, a także „nauczycieli w ściślejszym znaczeniu, np. lektorów”. Personelem pomocniczym mogły być tylko osoby legitymujące się dyplomem, ale takich kwalifikacji nie wymagano od lektorów ${ }^{3}$. Ich sytuacja była więc formalnie łatwiejsza niż nauczycieli szkół średnich, którzy musieli uzyskać uprawnienia do wykonywania zawodu. Podczas gdy wykwalifikowani nauczyciele cieszyli się jednak stabilną sytuacją finansową, lektorzy byli zatrudniani na godziny zlecone i nie mieli żadnej gwarancji pracy, a niskie zarobki plasowały ich na szarym końcu państwowego systemu edukacji.

Podstawowym źródłem informacji o lektorach są spisy wykładów na dany rok akademicki. Na USB prowadzili je kolejno: Anastazja Gruzińska, Alina Brylińska, Wanda Januszkiewiczówna i Władysław Kospoth-Pawłowski, a na UJ - Michał Dziewicki i Jan Stanisławski. Niniejszy artykuł prezentuje informacje zgromadzone między innymi w archiwach ${ }^{4}$, o lektorach wiemy bowiem bardzo mało.

\section{UNIWERSYTET STEFANA BATOREGO W WILNIE}

USB był jedynym uniwersytetem okresu międzywojnia bez katedry filologii angielskiej ${ }^{5}$. Nie ograniczało to kontaktów lektorów z krajami anglojęzycznymi ${ }^{6}$, ale

1 Z uwagi na brak miejsca pomijam tu lektorów innych uniwersytetów, jak i pozostałych szkół wyższych.

2 W monografii poświęconej historii UJ lektorom angielskiego poświęcono jedno zdanie, a w obszernym omówieniu historii Uniwersytetu Warszawskiego (dalej: UW) nie wymieniono żadnego lektora angielskiego. Zob. J. Dybiec, Uniwersytet Jagielloński w latach 1918-1939, Kraków 2000, s. 271; Dzieje Uniwersytetu Warszawskiego 1915-1945, red. P.M. Majewski, Warszawa 2016.

3 J. Dybiec, op. cit., s. 97.

4 Dokumenty w Lietuvos Centrinis Valstybès Archyvas [dalej: LCVA] w Wilnie są numerowane podwójnie. W cytowanych dokumentach podaję numer zapisany czarnym ołówkiem.

5 Katedrę filologii angielskiej w Krakowie prowadził Roman Dyboski, we Lwowie - Władysław Tarnawski, w Warszawie - Andrzej Tretiak, a w Poznaniu - B.W.A. Massey.

6 Jak wynika z analizy archiwów, troje lektorów planowało latem wyjazd do Wielkiej Brytanii. 
oznaczało brak zaplecza naukowego. Lektorzy w Wilnie nie mogli również liczyć na opiekę merytoryczną ${ }^{7}$ czy zaangażowanie w kształcenie studentów anglistyki, jak było to chociażby w Krakowie. Wyciąg ze spisu corocznych wykładów zawiera tabela 1 .

Tabela 1. Lista lektorów języka angielskiego, zakres zajęć i liczba godzin kursu na USB w latach 1919-1939

\begin{tabular}{|c|l|l|}
\hline Rok akademicki & \multicolumn{1}{|c|}{ Lektor } & \multicolumn{1}{c|}{ Opis kursów } \\
\hline $\begin{array}{c}1919 / 1920 \\
\text { półrocze zimowe) }\end{array}$ & Księżna Anastazja Gruzińska & $\begin{array}{l}\text { Kurs dla początkujących, 3 h } \\
\text { Kurs wyższy dla znających język } \\
\text { angielski, 2 h }\end{array}$ \\
\hline $\begin{array}{c}1919 / 1920 \\
\text { (półrocze letnie) }\end{array}$ & Księżna Anastazja Gruzińska & $\begin{array}{l}\text { Kurs dla początkujących, 3 h } \\
\text { Kurs dla posiadających język } \\
\text { angielski, 2 h }\end{array}$ \\
\hline $1920 / 1921$ & Lic. Alina Brylińska ${ }^{8}$ & $\begin{array}{l}\text { Kurs niższy, 2 h } \\
\text { Kurs średni, 2 h } \\
\text { Kurs wyższy, 2 h }\end{array}$ \\
\hline $1921 / 1922$ & Lic. Alina Brylińska & $\begin{array}{l}\text { Kurs niższy, 2 h } \\
\text { Kurs średni, 2 h } \\
\text { Kurs wyższy, 2 h }\end{array}$ \\
\hline $1922 / 1923$ & Lic. Alina Brylińska & $\begin{array}{l}\text { Kurs niższy, 3 h } \\
\text { Kurs wyższy, 3 h }\end{array}$ \\
\hline $1923 / 1924$ & Lic. Alina Brylińska & $\begin{array}{l}\text { Kurs niższy, 3 h } \\
\text { Kurs wyższy, 3 h }\end{array}$ \\
\hline $1924 / 1925$ & Lic. Alina Brylińska ${ }^{9}$ & $\begin{array}{l}\text { Kurs niższy, 3 h } \\
\text { Kurs wyższy, 3 h }\end{array}$ \\
\hline $1925 / 1926$ & Małgorzata Ihnatowicz ${ }^{10}$ & $\begin{array}{l}\text { Kurs wyższy, 3 h } \\
\text { Kurs niższy, 3 h }\end{array}$ \\
\hline $1926 / 1927$ & Wanda Januszkiewiczówna & $\begin{array}{l}\text { Kurs niższy, 2 h } \\
\text { Kurs wyższy, 2 h }\end{array}$ \\
\hline $1927 / 1928$ & Dr Wanda Januszkiewiczówna & $\begin{array}{l}\text { Kurs niższy, 3 h } \\
\text { Kurs średni, 2 h }\end{array}$ \\
\hline
\end{tabular}

7 Formalną opiekę merytoryczną nad lektorami, stanowiącą wymóg Ustawy o szkołach akademickich (art. 37, 1), sprawowali profesorowie Wydziału Humanistycznego. W roku 1933/1934 opiekę nad lektoratem języka angielskiego powierzono prof. Manfredowi Kridlowi, ale ograniczała się ona do jednorazowych hospitacji zajęć uzgodnionych z lektorem. LCVA, zesp. 175, 5 IV B 223, k. 62.

${ }^{8}$ Według dokumentów Brylińska objęła obowiązki lektora rok później (LCVA, zesp. 175, 1 I Bb 608, k. 6).

9 Jak wynika z pisma WH z 9 XII 1924 r., Brylińska „po wyjściu za mąż przeniosła się na stałe do Warszawy" (LCVA, zesp. 175, 5 IV B 41, k. 151).

${ }^{10}$ Gdy po wyjeździe Brylińskiej pojawił się wakat, Dyboski rekomendował na jej stanowisko J. Coopera, absolwenta Uniwersytetu Oksfordzkiego. Nie doszło jednak do jego zatrudnienia (LCVA, zesp. 175, 1 I Ba 43, k. 81) i ostatecznie lektorat objęła Wanda Januszkiewiczówna. 


\begin{tabular}{|c|c|c|}
\hline $1928 / 1929$ & Dr Wanda Januszkiewiczówna & $\begin{array}{l}\text { Kurs niższy, } 3 \text { h } \\
\text { Kurs średni, } 2 \text { h }\end{array}$ \\
\hline $1929 / 1930$ & Dr Wanda Januszkiewiczówna ${ }^{11}$ & $\begin{array}{l}\text { Kurs niższy, } 3 \mathrm{~h} \\
\text { Kurs wyższy, } 2 \mathrm{~h}\end{array}$ \\
\hline 1930/1931 & $\begin{array}{l}\text { Dr Wanda Januszkiewiczówna } \\
\text { (w I i II trym. na urlopie) }{ }^{12}\end{array}$ & $\begin{array}{l}\text { Kurs niższy, } 3 \text { h } \\
\text { Kurs wyższy, } 2 \text { h }\end{array}$ \\
\hline $1931 / 1932$ & Alina Studnicka & $\begin{array}{l}\text { Kurs niższy, } 2 \text { h } \\
\text { Kurs wyższy, } 2 \text { h }\end{array}$ \\
\hline $1932 / 1933$ & Alina Studnicka & $\begin{array}{l}\text { Kurs niższy, } 2 \text { h } \\
\text { Kurs wyższy, } 2 \text { h }\end{array}$ \\
\hline $1933 / 1934$ & Władysław Kospoth-Pawłowski ${ }^{13}$ & $\begin{array}{l}\text { Kurs niższy, } 2 \text { h } \\
\text { Kurs wyższy, } 2 \text { h }\end{array}$ \\
\hline \multirow[t]{2}{*}{$1934 / 1935$} & Władysław Kospoth-Pawłowski ${ }^{14}$ & Kurs niższy, 2 h \\
\hline & Alina Studnicka & Kurs wyższy, 2 h \\
\hline $1935 / 1936$ & N.N. ${ }^{15}$ & $4 \mathrm{~h}$ \\
\hline $1936 / 1937$ & Władysław Kospoth-Pawłowski & $\begin{array}{l}\text { Kurs niższy, } 2 \text { h } \\
\text { Kurs wyższy, } 2 \text { h }\end{array}$ \\
\hline $1937 / 1938$ & Władysław Kospoth-Pawłowski & $\begin{array}{l}\text { Kurs niższy, } 2 \text { h } \\
\text { Kurs wyższy, } 2 \text { h }\end{array}$ \\
\hline $1938 / 1939$ & Władysław Kospoth-Pawłowski & $\begin{array}{l}\text { Kurs niższy, } 2 \text { h } \\
\text { Kurs średni, } 2 \text { h }\end{array}$ \\
\hline
\end{tabular}

Źródło: Program wykładów i skład uniwersytetu w pótroczu zimowem roku akademickiego 1919/20 oraz Spis wykładów i sktad uniwersytetu w roku akademickim 1920/21-1938/39, Wilno.

Jak wynika z powyższego wykazu, początkowo uruchamiano zajęcia językowe na poziomie podstawowym (,kurs niższy”) i zaawansowanym („,kurs wyższy”), przeznaczając na każdy kurs trzy godziny tygodniowo, a w roku akademickim 1920/1921 oferowano także zajęcia na poziomie średnio zaawansowanym („kurs średni”). Od 1922 roku standardem były cztery godziny kursu tygodniowo, a większa liczba wymagała odpowiedniego umotywowania ${ }^{16}$.

Lektorzy byli zatrudniani na podstawie rocznych kontraktów, ale pensję wypłacano im tylko w czasie roku akademickiego, z pominięciem miesięcy wakacyjnych.

Tłumaczy to między innymi rotację nauczycieli, poszukujących bardziej stabilnych warunków pracy.

11 W I i II trymestrze Januszkiewiczówna była na urlopie w związku z wyjazdem do Anglii.

1218 XI 1930 r., pod nieobecność Januszkiewiczówny, kursy angielskiego rozpoczęła Brylińska (LCVA, zesp. 175, 5 IV B 190, k. 198).

${ }^{13}$ W roku akademickim 1933/1934 trzy godziny lektoratu zostały podzielone między Brylińską i Kospotha-Pawłowskiego.

${ }^{14}$ Po wyjeździe Studnickiej USB miał zatrudnić George'a Bridge'a z Shelley’s Institute w Wilnie. Ponieważ nie doszło do podpisania umowy, lektorat objął Kospoth-Pawłowski.

${ }_{15} 5$ X 1935 r. rada WH powierzyła lektorat Kospothowi-Pawłowskiemu (LCVA, zesp. 175, 1 I Bb 691, k. 3).

16 LCVA, zesp. 175, 5 IV B 41, k. 283. Do 1931 r. MWRiOP zgadzało się na prowadzenie pięciu godzin lektoratu angielskiego tygodniowo, a później tylko czterech godzin. 


\section{Anastazja Gruzińska}

Anastazja Nikołajewna Gruzińska (1880-1931) urodziła się 5 lutego 1880 roku w Petersburgu ${ }^{17}$ jako jedno z sześciorga dzieci księcia Nikołaja Gruzińskiego i księżnej Marii Katenin. W latach 1900-1916 pełniła funkcję honorowej damy dworu imperatorowej Rosji ${ }^{18}$.

Była świetnie wykształcona i znała wiele języków. W swoim życiorysie ${ }^{19}$ podaje informację, że do 1896 roku uczyła się prywatnie, maturę złożyła przy VI Gimnazjum w Petersburgu, a w latach 1905-1909 studiowała na Sorbonie i w Collège de France ${ }^{20}$. Kontakty z katolikami w Paryżu skłoniły ją do przejścia z prawosławia na katolicyzm $^{21}$, o czym pisze w swoich wspomnieniach ${ }^{22}$.

Około 1908 roku Gruzińska postanowiła uniezależnić się od rodziny i wróciła do Petersburga, aby zdać egzamin kwalifikacyjny dla nauczycieli. W maju 1909 roku została nauczycielką języka francuskiego w luterańskiej szkole w pałacu Finn, a w 1911 roku powierzono jej kierownictwo liceum żeńskiego w Mitawie (Kurlandia), w którym uczyła francuskiego i łaciny.

Po wybuchu I wojny światowej ewakuowała się do Petersburga, gdzie w lipcu 1915 roku została przełożoną luterańskiego Gimnazjum św. Piotra. W 1918 roku, po zwycięstwie rewolucji październikowej, złożyła do władz protest przeciwko dekretowi usuwającemu religię ze szkół ${ }^{23} \mathrm{i}$ wyjechała do Wilna. Otrzymała posadę nauczycielki niemieckiego w gimnazjum Anny Walerii Czarnowskiej i wykładała na „wyższych kursach handlowych przy Ognisku"24.

Po zajęciu Wilna przez Armię Czerwoną, 11 lutego 1919 roku Gruzińska została aresztowana przez bolszewików i osadzona w więzieniu. Po ofensywie wojsk polskich, które wkroczyły do Wilna 19 kwietnia, wyszła na wolność. Jak wynika z jej wspomnień ${ }^{25}$, wkrótce potem została „wciągnięta do współpracy w dziele Hoowera” i spędziła pół roku ,na ustawicznem podróżowaniu autem za frontem idących naprzód wojsk polskich"26.

17 LCVA, zesp. 175, 1 I Bb, 596, k. 2.

18 Zob. https://ru.wikipedia.org/wiki/ Список_фрейлин_российского_императорского_двора [dostęp: 11.09.2017].

19 LCVA, zesp. 175, 1 I Bb 596, k. 2.

20 Uczestniczyła w życiu towarzyskim arystokracji rosyjskiej we Francji, a do grona jej przyjaciół należeli m.in. pisarz Dmitrij Mereżkowski i jego żona, poetka Zinaida Gippius. Zob. Z. Gippiu s, Łaskowaja kobra. Swoja i Boż'ja, Moskwa 2015, s. 227.

${ }_{21}$ Z. Gippius, op. cit., s. 227.

22 A. Gruzińska, Moje nawrócenie, Poznań 1933.

23 Ibidem, s. 47. W 1917 r., gdy władzę w Rosji przejęli bolszewicy, rozpoczął się proces ograniczeń w sferze życia religijnego. Zob. G. Szubtarski, Antykościelne ustawodawstwo w ZSRR za rzadów Włodzimierza Lenina (1917-1923), „Kościół i Prawo” 2013, t. 2, z. 15, s. 66.

24 Informacja ta pochodzi z życiorysu Gruzińskiej. LCVA, zesp. 175, 1 I Bb 596, k. 2.

25 A. Gruzińska, op. cit., s. 58.

26 Misja Hoovera (Amerykańska Administracja Pomocy) działała w Polsce w latach 1919-1922. 
W październiku 1919 roku zatrudniono ją jako lektorkę angielskiego i francuskiego na USB ${ }^{27}$. Z propozycją prowadzenia lektoratu zwrócił się do niej prawdopodobnie Marian Zdziechowski ${ }^{28}$, który znał ją jeszcze z Paryża. W lipcu 1920 roku działalność USB została przerwana inwazją bolszewicką. Gruzińska wyjechała do Niemiec, a w 1921 roku - na Łotwę, gdzie zamierzała dalej prowadzić „pracę misyjną"29. Została dyrektorką Gimnazjum Polskiego w Dyneburgu, w którym uczyła łaciny ${ }^{30}$. W 1927 roku przeszła udar mózgu, czego skutkiem był paraliż ręki ${ }^{31}$. Zmarła w nocy z 11 na 12 lipca 1931 roku w klasztorze niedaleko Dyneburga ${ }^{32}$.

\section{Alina Brylińska (Studnicka)}

Alina Brylińska (1887-1976) urodziła się 7 marca 1887 roku w Kursku. Uczęszczała do rosyjskojęzycznego gimnazjum w Samarze, a po uzyskaniu świadectwa dojrzałości podjęła studia na Wydziale Humanistycznym Uniwersytetu w Lozannie (1906-1910) ${ }^{33}$, gdzie w 1912 roku otrzymała dyplom licencjacki ${ }^{34}$. Przez dwa kolejne lata studiowała na Sorbonie ${ }^{35}$, a w latach 1914-1915 była studentką Uniwersytetu Oxfordzkiego ${ }^{36}$. W czasie studiów udzielała prywatnych lekcji rosyjskiego, a do jej „uczniów” należał między innymi William Craigie, profesor Uniwersytetu Oksfordzkiego. Brylińska ukończyła studia, nie uzyskawszy jednak stopnia magistra ${ }^{37}$.

W 1915 lub 1916 roku otrzymała posadę nauczycielki francuskiego w szkole w St. Andrews (Szkocja) ${ }^{38}$. Dzięki referencjom profesora Craigie'ego zatrudniono ją

27 Tak pisze o tym w swojej książce: „W roku 1919, późną jesienią, nastąpiło otwarcie uniwersytetu wileńskiego. Zaproponowano mi objęcie na nim stanowiska lektorki. Nastąpiło kilka miesięcy cichej pracy w mieście, stopniowo powracającem do normalnego życia. Lecz w lipcu 1920 roku hordy bolszewickie znowu się wylały na Polskę. Trzeba było znowu uciekać”. A. Gruzińska, op. cit., s. 58.

28 Marian Zdziechowski (1861-1938) - historyk literatury, krytyk literacki i publicysta. W latach 1899-1919 profesor UJ, w latach 1919-1932 profesor USB.

29 I. Świrski, Stowo wstępne [w:] A. Gruzińska, op. cit., s. 8.

30 A. Durejko, Polskie życie kulturalne i literackie na Łotwie $w$ XX w., Wrocław 2001, s. 110.

31 I. Świrski, op. cit., s. 10.

32 Nezabytyje mogity. Rossijskoe zarubeże: nekrologi 1917-1999, t. 2: G-Z, Moskwa, red. E.W. Makarewicz, 1999, https://pomnirod.ru/materialy-k-statyam/захоронения/люксенбург/незабытыемогилы-российское зарубежье-некрологи-1917-2001-г.г/незабытые-могилы.-российскоезарубежье-некрологи-1917-1997.-том-2.-г-3.-1999.html [dostęp: 20.09.2017].

33 Catalogue des étudiants de l'Université de Lausanne. Année universitaire 1906-1910, https:// uniris.unil.ch/pandore/notice/catalogues-etudiants-unil/ [dostęp: 18.02.2018].

34 E-mail od Oliviera Roberta z Archiwum Uniwersytetu w Lozannie z 12 V 2017 r.

35 Potwierdza to jej życiorys i list rekomendacyjny Gastona Cahena. Józef Piłsudski Institute of America w Nowym Jorku [dalej: JPIA], W. Studnicki papers, zesp. 96, folder 1.

36 Należała do stowarzyszenia Society for Oxford Home Students.

37 Było to niemożliwe, gdyż Uniwersytet Oksfordzki zaczął nadawać kobietom stopnie naukowe dopiero od 1920 r. Zob. K. Studnicki-Gizbert, Moje wspomnienia z życia, które miatem, zdarzeń, które widziałem i nauk, które otrzymatem, Chelsea 2016, s. 50-51.

38 Wybuch rewolucji w Rosji, a wraz z nim brak pomocy finansowej od rodziców, zmusił ją do samodzielnego utrzymywania się. Zob. ibidem, s. 28. 
następnie jako lektorkę rosyjskiego w University of St. Andrews, w Technical College w Aberdeen i/lub w University College w Dundee, ale nie została formalnie członkiem grona nauczycielskiego ${ }^{39}$.

W 1919 roku ukazały się wypisy, Russian Fairy Tales..., przygotowane przez Brylińską we współpracy z Peterem Smithem. Latem 1919 roku nie przedłużono jej zatrudnienia na uczelniach $z$ uwagi na rzekome problemy zdrowotne ${ }^{40}$. Wcześniej w gazetach szkockich pojawiła się adnotacja, że została ukarana grzywną za zmianę miejsca zamieszkania bez poinformowania o tym policji, sugerująca jej możliwe sympatie rewolucyjne ${ }^{41}$.

Brylińska wróciła do Oksfordu, gdzie w latach 1919-1920 uczęszczała na wykłady z literatury francuskiej ${ }^{42}$. Następnie przeniosła się do Londynu, gdzie podjęła obowiązki sekretarki British Society for the Promulgation of English Language and Culture Abroad. Z Londynu wyjechała do Genewy, a później do Polski ${ }^{43}$. W liście do Stefana Glixelliego pisała:

Bardzo bym chciała wrócić do Kraju i kandydatura, o której Sz. Pan pisze, mnie b. interesuje [...] Bardzo bym była Panu wdzięczna za udzielenie mi informacji i detali w sprawie lektoratu przy Uniwersytecie w Wilnie, gdyż byłoby mi niezmiernie przyjemnie dla Kraju pracować ${ }^{44}$.

Mając ponoć możliwość objęcia bardziej intratnej posady w Bułgarii ${ }^{45}$, zdecydowała się przyjąć propozycję pracy w Wilnie. W latach 1921-1924 prowadziła lektorat angielskiego i francuskiego, a od roku 1924/1925 - po zatrudnieniu na stanowisku lektora francuskiego Małgorzaty Ihnatowicz - tylko angielskiego.

Wiele wskazuje na to, że Brylińska miała zacięcie naukowo-literackie. W czasie wakacyjnych kursów językowych w Genewie w 1923 roku zamierzała zająć się naukowo twórczością Jeana-Jacques'a Rousseau ${ }^{46}$. Pracowała również nad przygotowaniem podręcznika do nauki angielskiego. Być może z braku środków nie napisała jednak doktoratu ani nie zdołała wydać podręcznika ${ }^{47}$.

W 1924 roku poślubiła Władysława Studnickiego-Gizberta, polityka i publicystę o orientacji proniemieckiej. Małżonkowie przenieśli się do Warszawy, gdzie

39 Wraz z trzema innymi pracownikami Gordon Technical College Brylińską potraktowano jako „special case”. Technical College Salaries, „The Aberdeen Daily Journal”, 19 XII 1918, 19958, s. 6.

40 University of St. Andrews Archives, Records A/25.

41 Russian Lady Lecturer Fined at Cupar, „Evening Telegraph and Post”, 5 VI 1917, 12644, s. 3.

42 P.A. Tribunskij, Alina Brylinskaja (Brilinskaja) i rossiewedenie w Welikobritanii, „Klio” 2016, t. 8 , z. 1 , s. 110 .

43 Do powrotu miał ją namówić Marian Zdziechowski (e-mail od prof. K. Studnickiego-Gizberta z 8 V 2017 r.), ale korespondencję w sprawie zatrudnienia prowadził Stefan Glixelli.

44 LCVA, zesp. 175, 5 IV B 41, k. 246 i in.

45 E-mail od prof. K. Studnickiego-Gizberta z 8 V 2017 r.

46 Pismo Mariana Zdziechowskiego do Rektora USB z 22 VI 1923 r. LCVA, zesp. 175, 1 I Bb 598, k. 17.

47 Brylińska wystąpiła z wnioskiem o dodatkowe środki do wysokości 300 franków szwajcarskich, potrzebne na wydanie podręcznika. WH nie przyznał jej jednak wnioskowanej kwoty. Zob. LCVA, zesp. 175, 5 IV B 41, k. 206. 
Studnicka była lektorką angielskiego w Wolnej Wszechnicy Polskiej ${ }^{48}$. W 1926 roku urodził się im syn Konrad.

W 1930 roku Studniccy wrócili do Wilna. Studnicka uczyła angielskiego na USB przez trzy lata. Prowadziła również Koło Miłośników Języka Angielskiego, dla którego zamawiała anglojęzyczne książki. W piśmie z 1 grudnia 1931 roku informuje Dziekana WH:

W roku zeszłym z różnych wydziałów i od osób prywatnych otrzymałam 175 zł. Za tę sumę są zamówione:

Jespersena Gramatyka Angielska 3 tomy (76 zł)

Galsworthy'ego - Teatr (12 zł)

Eltona Współczesna Literatura Angielska 2 tomy (zł 37) i na pozostałą sumę co bibljoteka używanych książek Timesa będzie mogła przysłać.

Pożądane byłoby mieć całego Eltona (10 tomów) i Oxford Dictionary ${ }^{49}$.

Troska o zapewnienie odpowiednich materiałów dydaktycznych świadczy jak najlepiej o lektorce.

W 1933 roku władze USB postanowiły zaproponować jej stanowisko komuś innemu $^{50}$. Pismo Studnickiej z 8 września 1933 roku zawiera gorzkie przemyślenia: „Obecnie prywatnie dowiedziałam się, że Wydział Humanistyczny USB z nieznanych mi bliżej przyczyn pominął mnie i przedstawił kandydaturę innej osoby na objęcie lektoratu języka angielskiego. Czuję się tem [...] ogromnie pokrzywdzona i dotknięta" 51 .

Po zatrudnieniu Władysława Kospotha-Pawłowskiego w roku akademickim 1933/1934 Studnicka uzyskała zgodę na pracę w wymiarze zaledwie jednej godziny. Nic dziwnego, że po zakończeniu zajęć we wrześniu 1934 roku odeszła z USB. Studniccy przenieśli się z powrotem do Warszawy, gdzie Alina uczyła w szkole dla obcokrajowców pod auspicjami Konsulatu Brytyjskiego ${ }^{52}$.

Po wybuchu II wojny światowej pozostawała prawdopodobnie bez pracy. W 1941 roku, po aresztowaniu męża przez Gestapo, sama opiekowała się nastoletnim synem. W lipcu 1944 roku rodzina opuściła Warszawę - wyjechała na Węgry, a później do Tyrolu, gdzie w 1945 roku Studnicka była tłumaczką dla Amerykanów stacjonujących w Kitzbühel $^{53}$. W sierpniu 1945 roku wyjechali do Włoch ${ }^{54}$, osiedlając się później w Rzymie ${ }^{55}$, gdzie latem 1946 roku Studnicka pracowała jako lektorka angielskiego i francuskiego przy II Korpusie Polskich Sił Zbrojnych na Zachodzie.

48 Wolna Wszechnica Polska. Sprawozdanie z działalności w roku akademickim 1925/26, Warszawa 1926, s. 72.

49 LCVA, zesp. 175, 5 IV B 190, k. 102.

50 Być może jej problemy wynikały z nacisków władz sanacyjnych na USB ze względu na działalność polityczną jej męża.

51 LCVA, zesp. 175, 5 IV B 223, k. 260.

52 JPIA, W. Studnicki papers, zesp. 96, folder 1, Curriculum Vitae.

53 Rękopiśmienny życiorys Studnickiej. JPIA, W. Studnicki papers, zesp. 96, folder 1, Curriculum Vitae.

${ }^{54}$ JPIA, W. Studnicki papers, zesp. 96, folder 1, Soggiorno degli Stranieri in Italia.

55 P.A. Tribunskij, op. cit., s. 111. 
We Włoszech Władysław Studnicki zaczął czynić starania o wyjazd całej rodziny do Stanów Zjednoczonych ${ }^{56}$. W obliczu problemów zdecydowali się na emigrację do Wielkiej Brytanii. Jak wynika z życiorysu Studnickiej, w latach 1946-1947 uczyła angielskiego w Polskim Kolegium Uniwersyteckim, tak zwanym PUC-u, w Londynie. Od 1950 roku poświęciła się opiece nad schorowanym mężem aż do jego śmierci w 1953 roku. W latach 1955-1960 pracowała społecznie jako thumaczka w szpitalach i sądach brytyjskich. Na początku lat 60 . wyjechała do syna do Kanady. Zmarła w Toronto w 1976 roku.

\section{Wanda Januszkiewiczówna (Grabińska)}

Wanda Januszkiewiczówna (1901-1995) urodziła się w Kijowie 5 lutego 1901 roku $^{57}$. Była córką Aleksandra Januszkiewicza ${ }^{58}$ oraz Janiny z Peszyńskich. Języka angielskiego uczyła się prywatnie już jako dziecko. W 1914 roku została przyjęta do III klasy polskiego gimnazjum filologicznego Wacławy Peretjatkowiczowej w Kijowie, które ukończyła 21 maja 1919 roku, otrzymując świadectwo dojrzałości.

W 1919 roku rodzina przeniosła się do Warszawy, a Wanda immatrykulowała się na Wydziale Filozoficznym Uniwersytetu Warszawskiego. We wrześniu 1921 roku przeniosła się na UJ, gdzie studiowała między innymi wraz z Henrykiem Baryczem i Williamem Rose ${ }^{59}$. Uczęszczała na seminarium Stanisława Kota i ukończyła studia w 1924 roku. 29 listopada 1924 roku zdała ,rigorozum” z filozofii, a 18 czerwca 1927 roku złożyła „wielkie rigorozum”, zdając pomyślnie egzamin z literatury polskiej, języka polskiego i literatury angielskiej. Ponieważ w całym toku studiów nie miała żadnych zajęć anglojęzycznych, musiała samodzielnie przygotować się do egzaminu ${ }^{60}$.

Na stanowisko lektora języka angielskiego na USB rekomendował Januszkiewiczównę Roman Dyboski ${ }^{6}$. Była zatrudniona w latach 1926-1930, ale o jej pracy dydaktycznej nie ma żadnych informacji. Nie wiadomo też, jak aktywnie angażowała się w szerzenie wiedzy o kulturze angielskiej, ale warto odnotować, że w październiku 1928 roku wygłosiła odczyt radiowy „Chesterton o pracy kobiet”62.

56 M. Figura, Rosja w myśli politycznej Wtadystawa Studnickiego, Poznań 2008, s. 69-70.

57 AUJ, WF II 504; AUJ, S II 308a.

58 Aleksander Januszkiewicz (1872-1955) - profesor nauk medycznych na USB, rektor tej uczelni w latach 1930-1932.

59 H. Baryc z, Wspomnienie o ks. Stanisławie Bednarskim, „Pamiętnik Literacki” 1946, t. 36, z. 1/2, s. 11. William J. Rose (1885-1968) - Kanadyjczyk, absolwent Uniwersytetu w Manitobie, stypendysta Rhodesa, absolwent Uniwersytetu Oksfordzkiego, doktor WF UJ. Zob. P. Auty, William J. Rose, „The Slavonic and East European Review" 1969, t. 47, z. 100, s. 8; T. Pudłocki, Ambasadorzy idei. Wkład intelektualistów w promowanie pozytywnego wizerunku Polski w Wielkiej Brytanii w latach 1918-1939, Kraków 2015, s. 59, 191, 193, 261.

${ }^{60}$ AUJ, S II 308a, WF II 504, Absolutorium.

${ }_{61}$ LCVA, zesp. 175, 1 I Bb 598, k. 5.

62 „Kurier Warszawski”, 29 X 1928, s. 4. 
Latem 1926 roku Januszkiewiczówna wzięła udział w kursie językowym na Uniwersytecie Londyńskim ${ }^{63}$. W kwietniu 1929 roku wystąpiła o urlop naukowy w roku akademickim 1929/1930, pragnąc wykorzystać go „dla dalszych studjów w Anglji nad literaturą i językiem angielskim" ${ }^{64}$. W 1930 roku otrzymała stypendium z Zarządu Funduszu Kultury Narodowej na studia w Wielkiej Brytanii, ale prawdopodobnie z niego zrezygnowała ${ }^{65} .4$ listopada 1930 roku wyszła za mąż za Mieczysława Grabińskiego ${ }^{66}$, dyplomatę, wówczas konsula RP w Czerniowcach (Rumunia), i w tym samym roku złożyła rezygnację ze stanowiska lektora ${ }^{67}$. Nie oznaczało to jednak, że przestała interesować się językiem angielskim ${ }^{68}$.

W 1931 roku urodziła się córka Grabińskich Anna, a w 1935 roku - syn Jerzy. W tym samym roku Grabiński został konsulem generalnym RP w Wiedniu. Wanda pełniła obowiązki żony dyplomaty ${ }^{69}$.

W marcu 1939 roku Grabiński został konsulem w Monachium i tu zastał małżeństwo wybuch wojny ${ }^{70} .1$ września 1939 roku zostali internowani, przewiezieni do Wiednia, a następnie przekazani przez Niemców stronie węgierskiej. W listopadzie 1939 roku przenieśli się z Budapesztu do Zagrzebia. 14 kwietnia 1941 roku, po napadzie Niemiec na Jugosławię, zostali aresztowani przez chorwackich ustaszy i wydani w ręce Gestapo ${ }^{71}$. Przewieziono ich do więzienia w Grazu. Grabińską zwolniono 28 maja 1941 roku, zezwalając na przejściowe zamieszkanie w mieście z obowiązkiem meldowania się na Gestapo.

5 lipca 1941 roku przewieziono ich do Monachium; męża Grabińskiej umieszczono w więzieniu Gestapo, ją natomiast skierowano do pracy przymusowej ${ }^{72}$. Miesiąc później Grabiński został przewieziony do niemieckiego obozu koncentracyjnego w Dachau ${ }^{73}$, a jego żona pozostała w Monachium ${ }^{74}$. W 1943 roku uzyskała z Berlina

63 LCVA, zesp. 175, 5 IV B 41, k. 46.

64 Ibidem, k. 609.

65 Dzienniki: 1930-1936, red. B. Żongołłowicz, D. Zamojska, Warszawa 2004, s. 33.

66 Ślubu udzielił bp Władysław Bandurski, były kapelan I Brygady Legionów. S.T. Olejnik, Wstęp [w:] M. Grabiński, Wieluń na przełomie wieków, Wieluń 2009, s. 7-12.

${ }_{67} \mathrm{~W}$ archiwach USB znajduje się podziękowanie Rektora USB za kilkuletnią „,gorliwą pracę” lektora. LCVA, zesp. 175, 5 IV B 190, k. 245.

68 Świadczy o tym m.in. treść listu gratulacyjnego, jaki skierowała 12 V 1934 r. do Romana Dyboskiego z okazji 25-lecia jego pracy, w którym dzieliła się uwagami na temat współczesnej literatury angielskiej. Archiwum Nauki PAN i PAU w Krakowie, Spuścizna Romana Dyboskiego, sygn. K III-90 (w opracowaniu).

69 W.S. Kucharski [Biogram M. Grabińskiego] [w:] M. Grabiński, Dyplomacja w Dachau..., Łowicz 2007.

70 Mając świadomość zbliżającej się wojny, w lipcu 1939 r. Grabińska odwiozła dzieci do swoich rodziców do Druskiennik.

${ }_{71}$ M. Grabiński, op. cit., s. 69.

72 Początkowo chciano ją skierować do pracy w fabryce zbrojeniowej, ale ostatecznie zezwolono jej na pracę w charakterze nauczyciela języków obcych. Ibidem, s. 80 .

73 Ibidem, s. 94.

74 Mieszkała w ,jakichś nieodpowiednich wynajętych pokojach, potem w schronisku kobiet katolickich, aż wreszcie pod koniec 1942 roku wprowadziła się do małego mieszkanka, należącego do p. dr. L., 
zgodę na krótki pobyt w Wilnie ${ }^{75}$, gdzie do końca wojny udzielała prywatnych lekcji angielskiego ${ }^{76}$.

We wrześniu 1945 roku Grabińska wyjechała w ramach repatriacji do Kalisza. W 1946 roku wydała książkę do nauki języka angielskiego Let Us Try. W 1947 roku, przechodząc wraz z dziećmi przez zieloną granicę, dołączyła do męża w Monachium $^{77}$. W Niemczech pracowała jako tłumaczka amerykańskich władz strefy okupacyjnej w Bawarii ${ }^{78}$.

W 1949 roku Grabińscy wyjechali do Londynu, gdzie Wanda podjęła pracę w Stowarzyszeniu Polskich Kombatantów ${ }^{79}$, pełniąc jednocześnie funkcję sekretarki Polskiego Związku b. Więźniów Politycznych Obozów Koncentracyjnych ${ }^{80}$ oraz thumaczki w konsulacie niemieckim ${ }^{81}$. Jej mąż czynnie uczestniczył w życiu politycznym ${ }^{82}$. W połowie lat 50. przeszedł zawał ${ }^{83}$, po którym Grabińska zrezygnowała z pracy.

Po śmierci męża, od 1960 roku współdziałała przy budowie Polskiego Ośrodka Społeczno-Kulturalnego w Londynie, a przez wiele lat była sekretarką w Instytucie Józefa Piłsudskiego. Zmarła w Londynie 19 października 1995 roku.

\section{Władysław Kospoth-Pawłowski}

Władysław Kospoth-Pawłowski (1894-1946) urodził się 16 lipca 1894 roku w Drzycimiu koło Świecia ${ }^{84}$. Był uczniem Gimnazjum Humanistycznego w Brodnicy, a w 1914 roku wstąpił na Wydział Filologiczny Uniwersytetu Berlińskiego. W 1915 roku, po wybuchu I wojny światowej, powołano go do wojska pruskiego. W 1916 roku przeszedł kurs podoficerski w Ostend, a w 1918 roku - w Blankenberghe

dyrektorki gimnazjum, w charakterze gospodyni, kucharki, pokojówki [...] mogła wreszcie dawać naukę języka angielskiego". Ibidem, s. 204.

75 Ibidem, s. 207.

76 W liście do męża wiosną 1944 r. pisze: „Ja dużo pracuję, mam wiele lekcji prywatnych w kompletach". Ibidem, s. 208.

771 XI 1945 r. Grabiński został delegatem ministra spraw zagranicznych rządu emigracyjnego w amerykańskiej strefie okupacyjnej Niemiec S.T. Olejnik, op. cit., s. 12.

78 Informację tę uzyskałam od Hanny Grabińskiej.

79 SPK, założone w 1946 r. w Londynie, było organizacją społeczną, mającą na celu samopomoc. Zob. J. Szmidt, Biblioteki polskie we wspótczesnym Londynie, Warszawa 1998, s. 15.

${ }^{80}$ Grabiński angażował się również, przy aktywnym udziale żony, w walkę o uzyskanie rekompensat dla byłych pracowników służby dyplomatycznej, którzy przebywali w obozach koncentracyjnych. Archiwum Instytutu Polskiego i Muzeum im. gen. Sikorskiego w Londynie [dalej: AIPMS], A44.123/10, k. 387-388, 395-401.

81 Informację tę uzyskałam od Hanny Grabińskiej.

82 Był m.in. prezesem Stowarzyszenia Pracowników Polskiej Służby Dyplomatycznej oraz Polskiego Związku b. Więźniów Politycznych Obozów Koncentracyjnych, a także członkiem IV Rady Narodowej RP. S.T. Olejnik, op. cit., s. 12.

83 W Dachau zachorował na dusznicę bolesną. Zob. AIPMS, A44.123/10, k. 401.

${ }^{84}$ Jego ojciec Mieczysław Pawłowski, właściciel ziemski, wywodził się z saksońskiego rodu Kospothów. 
(Belgia), uzyskując stopień sierżanta ${ }^{85}$. Za zasługi na polu walki został odznaczony Krzyżem Żelaznym II klasy ${ }^{86}$.

Po zakończeniu wojny powrócił w rodzinne strony i przyjął polskie obywatelstwo. 5 maja 1919 roku wstąpił do Wojska Polskiego. W latach 1919-1920 walczył w wojnie polsko-bolszewickiej, awansując od podchorążego do podporucznika ${ }^{87}$. W lutym 1922 roku przeszedł do rezerwy i przeniósł się do Wilna. Jak wynika z materiałów NKWD ${ }^{88}$, w latach 1922-1924 miał być korespondentem brytyjskiej firmy zajmującej się handlem drewnem ${ }^{89}$. Brakuje informacji, czym zajmował się w kolejnych latach. Być może podjął przerwane przez wojnę studia językowe ${ }^{90}$, ale nie uzyskał dyplomu uczelni.

W 1926 roku został zatrudniony jako nauczyciel francuskiego w Gimnazjum im. Adama Mickiewicza w Wilnie, a kilka lat później zaczął wykładać angielski w Instytucie Nauk Handlowo-Gospodarczych. Około 1926 roku ożenił się z Marią Wyganowską, adiunktem kancelaryjnym w Sądzie Apelacyjnym w Wilnie.

W 1930 roku Kospoth-Pawłowski wydał podręcznik do nauki angielskiego, którego rewizji podjęła się Wanda Januszkiewiczówna. W 1931 roku nawiązał kontakt z Charlesem K. Ogdenem, dyrektorem Instytutu Ortologicznego, nadzorującym rozwój języka Basic ${ }^{91}$. W latach 1932-1934 wydawał z własnej inicjatywy czasopismo „Basic News”, a w 1933 roku ukazał się Stownik angielsko-polski. Wstępny stowniczek do Basic English na podstawie "The Basic Words" C.K. Ogdena z krótka gramatyk ${ }^{92}$.

W 1933 roku Kospothowi-Pawłowskiemu zaproponowano posadę lektora angielskiego na USB, gdzie pracował do wybuchu II wojny światowej. Na temat jego pracy dydaktycznej nie ma jednak informacji ${ }^{33}$. Kilkakrotnie wyjeżdżał do Wielkiej Brytanii ${ }^{94}$. W związku z planowanym w 1936 roku wyjazdem wyjaśniał:

${ }_{85}$ Z armią pruską przemierzył szlakiem bitew I wojny światowej prawie całą Europę. Zob. W. Kospoth-Pawłowski, Odwrót. Fragmenty [w:] Na szlaku Batorego, Wilno 1926, s. 76-80.

${ }^{86}$ Centralne Archiwum Wojskowe [dalej: CAW], sygn. AP 1518.

87 Za zasługi w walkach z Armią Czerwoną 1 V 1919 r. uzyskał stopień podporucznika. CAW, sygn. AP 1518.

${ }_{88}$ NKWD (Narodnyj Komissariat Wnutriennich Dieł) - Ludowy Komisariat Spraw Wewnętrznych. Zob. CAW, sygn. VIII.809.67.

89 Być może chodzi tu o Polską Spółkę Akcyjną „Century”. W dokumentach firmy w Archiwum Akt Nowych [dalej: AAN] w Warszawie brak jednak odniesień do Kospotha-Pawłowskiego. AAN, zesp. 252, Polska Spółka Drzewna CENTURY. Anglo-Europejskie Towarzystwo Akcyjne. Zastępstwo na Polskę, 1924-1931, 1935.

90 Według Sprawozdania dyrekcji gimnazjum oo. Jezuitów w Wilnie... za rok szkolny 1927/28 (Wilno 1928, s. 24) Kospoth-Pawłowski ukończył studia w Berlinie i Poitiers.

${ }_{91}$ Basic (English) był stworzonym przez brytyjskich językoznawców C.K. Ogdena i I.A. Richardsa językiem uniwersalnym. Korespondencja Kospotha-Pawłowskiego z Instytutem znajduje się w Archives and Research Collections of McMaster University w Hamilton (Kanada).

92 Zob. M. Podhajecka, A History of Polish-English / English-Polish Bilingual Lexicography, Opole 2016, s. 377-385.

93 Dziekan WH, T. Czyżewski, popierając cel wyjazdu Kospotha-Pawłowskiego za granicę, ocenia krótko: „petent od trzech lat pełni obowiązki lektora języka angielskiego, wywiązując się należycie z włożonych na niego obowiązków". LCVA, zesp. 175, 1 I Bb 691, k. 5.

94 Informacja od Eugenii Chmary, której mąż był siostrzeńcem Kospotha-Pawłowskiego. 
Z uwagi na okoliczność, iż należę do bardzo szczupłego grona tych, którzy poświęcając się opracowywaniu najnowszego materiału do podręczników naszych szkół, są zmuszeni pozostawać w bezpośredniej styczności z danym krajem, żywię nadzieję, iż Ministerstwo, w uznaniu powyższej konieczności, zechce przychylić się do mej prośby i udzieli mi bezpłatnego paszportu, względnie przedłuży pobyt w Anglji ${ }^{95}$.

W latach 1938-1939 uczył angielskiego także w Liceum im. Jana i Jędrzeja Śniadeckich utworzonym przy $\mathrm{USB}^{96}$. Po latach były uczeń liceum, Tadeusz Kowzan, wspominał: „Anglomanii dyrektora ${ }^{97}$ zawdzięczaliśmy też, że jako przedmiot nadobowiązkowy wprowadzony został język angielski, którego uczył nas znakomity anglista Kospoth-Pawłowski"98.

3 czerwca 1941 roku, po ataku Niemiec na ZSRR, Kospoth-Pawłowski został aresztowany przez NKWD ${ }^{99}$. Odzyskał wolność po wkroczeniu do Wilna oddziałów Wehrmachtu. W lipcu 1944 roku, po zdobyciu Wilna przez Armię Czerwoną, pozostał w mieście. 3 marca 1945 roku NKWD przeprowadziła rewizję w jego mieszkaniu, po której został aresztowany i osadzony w więzieniu. Zarzucono mu między innymi posiadanie literatury antyradzieckiej i współpracę z brytyjskim wywiadem ${ }^{100}$.

30 października 1945 roku wyrokiem sądu w Wilnie Kospoth-Pawłowski został skazany z art. 58 par. 6 sowieckiego kodeksu karnego na pięcioletni pobyt w poprawczym obozie pracy. Dodatkowo, na mocy art. 208 kodeksu postępowania karnego, sprawę postanowiono przekazać do oddzielnego rozpatrzenia. W październiku 1945 roku przewieziono go z Wilna do Moskwy. Ciężkie warunki więzienne i brutalne metody przesłuchań NKWD spowodowały gwałtowne pogorszenie się jego stanu zdrowia. 26 lutego 1946 roku umarł w szpitalu więzienia śledczego na Butyrkach. Miejsce jego pochówku jest nieznane.

\section{UNIWERSYTET JAGIELLOŃSKI W KRAKOWIE}

UJ zajmuje poczesne miejsce w historii myśli anglistycznej w Polsce, ponieważ to tu otwarto pierwszą w Polsce katedrę anglistyki prowadzoną przez Romana Dyboskiego.

95 Jak wynika z pisma, cel planowanego latem wyjazdu miał być „ściśle naukowy, związany z kilkuletnią współpracą [...] z the Orthological Institute”. Dodatkowo lektor zamierzał „słuchać wykładów prof. Daniela Jonesa i innych przy Uniwersytecie Londyńskim celem pogłębienia swych wiadomości z dziedziny anglistyki". LCVA, zesp. 175, 1 I Bb, 691, k. 5.

96 A. Ulińska, Państwowe Liceum im. Jana i Jędrzeja Śniadeckich w Wilnie (1938-1939), Białystok 1996, s. 9, 38, 97.

${ }_{97}$ Prof. Wacław Staszewski, wybitny fizyk, inicjator i dyrektor liceum, przebywał niegdyś na stażu naukowym w University College London. Zob. H. Piersa, Staszewski Wactaw (1892-1970) [w:] Polski Stownik Biograficzny [dalej: PSB], t. 42, 2004, z. 4, s. 536.

98 A. Ulińska, op. cit., s. 207.

99 CAW, sygn. VIII.809.67.

100 Ibidem. 
W latach 1818-1833 pierwsze zajęcia z języka angielskiego na UJ prowadził hellenista, profesor Herman Schugt ${ }^{101}$. Potem nastąpiła 50-letnia przerwa w nauczaniu angielskiego. Kolejnymi lektorami byli: Bolesław Ziołecki, uczący w latach 1883$1896^{102}$, i Michał Dziewicki, pracujący w latach 1896-1927 ${ }^{103}$. W 1928 roku lektorat angielskiego prowadził przez trzy miesiące Anglik Godfrey Greene. Pedagogiem, którego nazwisko wiąże się nierozerwalnie z Krakowem, był Jan Stanisławski, zatrudniony w UJ od 1928 do 1958 roku $^{104}$. Listę lektorów i zakres zajęć w UJ w latach 1918-1939 podaje tabela 2.

Tabela 2. Lista lektorów języka angielskiego, zakres zajęć i liczba godzin kursu na UJ w latach 1919-1939

\begin{tabular}{|c|l|l|}
\hline Rok akademicki & \multicolumn{1}{|c|}{ Lektor } & \multicolumn{1}{c|}{ Opis kursu } \\
\hline $\begin{array}{c}1919 / 1920 \\
\text { semestr zimowy) }\end{array}$ & Michał H. Dziewicki & $\begin{array}{l}\text { Kurs elementarny, 2 h } \\
\text { Ćwiczenia ustne i pisemne, 2 h } \\
\text { Tłumaczenie i objaśnianie autorów klasycznych, 2 h }\end{array}$ \\
\hline $\begin{array}{c}1919 / 1920 \\
\text { semestr letni) }\end{array}$ & Michał H. Dziewicki & $\begin{array}{l}\text { Kurs elementarny, 3 h } \\
\text { Ćwiczenia ustne i piśmienne (tylko dla tych, którzy } \\
\text { już mówią po angielsku), 2 h } \\
\text { Tłumaczenie i objaśnianie autorów klasycznych, 1 h }\end{array}$ \\
\hline $\begin{array}{c}\text { 1920/1921 } \\
\text { (semestr zimowy) }\end{array}$ & Michał H. Dziewicki & $\begin{array}{l}\text { Kurs elementarny, 2 h } \\
\text { Ćwiczenia ustne i piśmienne, 2 h } \\
\text { Tłumaczenie i objaśnianie autorów klasycznych, 2 h }\end{array}$ \\
\hline $1920 / 1921$ & Michał H. Dziewicki & $\begin{array}{l}\text { Kurs elementarny, 2 h } \\
\text { Ćwiczenia ustne i piśmienne (dla więcej umiejących } \\
\text { uczniów), 2 h } \\
\text { Tłumaczenie i objaśnianie autorów klasycznych, 2 h }\end{array}$ \\
\hline $1921 / 1922$ & Michał H. Dziewicki & $\begin{array}{l}\text { Kurs elementarny, 2 h } \\
\text { Ćwiczenia ustne i piśmienne, 2 h } \\
\text { Tłumaczenie i objaśnienie autorów klasycznych, 2 h }\end{array}$ \\
\hline $1922 / 1923$ & Michał H. Dziewicki & $\begin{array}{l}\text { Kurs elementarny, 2 h } \\
\text { Ćwiczenia ustne i piśmienne, 2 h } \\
\text { Tłumaczenie i wyjaśnianie autorów klasycznych, } \\
\text { 2 h }\end{array}$ \\
\hline $1923 / 1924$ & Michał H. Dziewicki & $\begin{array}{l}\text { Ćwiczenia ustne i piśmienne, 3 h } \\
\text { Tłumaczenie i wyjaśnianie autorów klasycznych, } \\
\text { 3 h }\end{array}$ \\
\hline
\end{tabular}

101 Z. Mazur, Sto lat Instytutu Filologii Angielskiej Uniwersytetu Jagiellońskiego, Kraków 2011, s. 9.

102 Dr Bolesław Ziołecki, filolog klasyczny, był nauczycielem języka francuskiego przy Królewskiej Wyższej Szkole Realnej w Gliwicach.

103 P. Mroczkowski, Historia Katedry Filologii Angielskiej w Uniwersytecie Jagiellońskim [w:] Wydziat Filologiczny Uniwersytetu Jagiellońskiego. Historia katedr, red. W. Taszycki, A. Zaręba, Kraków 1964, s. 337.

104 AUJ, S II 619. 


\begin{tabular}{|c|c|c|}
\hline $1924 / 1925$ & Michał H. Dziewicki & $\begin{array}{l}\text { Ćwiczenia ustne i pisemne, } 3 \mathrm{~h} \\
\text { Tłumaczenie i wyjaśnianie autorów klasycznych, } \\
3 \mathrm{~h}\end{array}$ \\
\hline $1925 / 1926$ & Michał H. Dziewicki & $\begin{array}{l}\text { Ćwiczenia ustne i pisemne, } 3 \mathrm{~h} \\
\text { Tłumaczenie i wyjaśnianie autorów klasycznych, } \\
3 \mathrm{~h}\end{array}$ \\
\hline $1926 / 1927$ & $\begin{array}{l}\text { Michał H. } \\
\text { Dziewicki }^{105}\end{array}$ & $\begin{array}{l}\text { Ćwiczenia ustne i pisemne, } 3 \mathrm{~h} \\
\text { Tłumaczenie i wyjaśnianie autorów klasycznych, } \\
3 \mathrm{~h}\end{array}$ \\
\hline $1927 / 1928$ & $\begin{array}{l}\text { Michał H. } \\
\text { Dziewicki }^{106}\end{array}$ & $\begin{array}{l}\text { Ćwiczenia ustne i pisemne, } 3 \mathrm{~h} \\
\text { Tłumaczenie i wyjaśnianie autorów klasycznych, } \\
3 \mathrm{~h}\end{array}$ \\
\hline $1928 / 1929$ & Jan Stanisławski & $\begin{array}{l}\text { Kurs niższy, } 2 \mathrm{~h} \\
\text { Kurs wyższy, } 2 \mathrm{~h} \\
\text { Kurs dla studentów filologii angielskiej, } 2 \mathrm{~h}\end{array}$ \\
\hline $1929 / 1930$ & Jan Stanisławski & $\begin{array}{l}\text { Kurs dla początkujących, } 2 \mathrm{~h} \\
\text { Kurs dla zaawansowanych, } 2 \mathrm{~h} \\
\text { Lektura angielska, } 2 \mathrm{~h}\end{array}$ \\
\hline $1930 / 1931$ & Jan Stanisławski & $\begin{array}{l}\text { Kurs dla początkujących, } 2 \mathrm{~h} \\
\text { Kurs dla zaawansowanych, } 2 \mathrm{~h} \\
\text { Lektura angielska, } 2 \mathrm{~h}\end{array}$ \\
\hline $1931 / 1932$ & Jan Stanisławski & $\begin{array}{l}\text { Kurs dla początkujących, } 2 \mathrm{~h} \\
\text { Kurs dla zaawansowanych, } 2 \mathrm{~h} \\
\text { Lektura angielska, } 2 \mathrm{~h}\end{array}$ \\
\hline $1932 / 1933$ & Jan Stanisławski & $\begin{array}{l}\text { Kurs dla początkujących, } 2 \mathrm{~h} \\
\text { Proseminarium angielskie, } 2 \mathrm{~h} \\
\text { Kurs dla zaawansowanych, } 2 \mathrm{~h}\end{array}$ \\
\hline $1933 / 1934$ & Jan Stanisławski ${ }^{107}$ & $\begin{array}{l}\text { Język dla początkujących, } 2 \mathrm{~h} \\
\text { Język dla zaawansowanych, } 2 \mathrm{~h} \\
\text { Proseminarium, } 2 \mathrm{~h}\end{array}$ \\
\hline $1934 / 1935$ & Jan Stanisławski & $\begin{array}{l}\text { Kurs początkowy, } 2 \mathrm{~h} \\
\text { Kurs średni, } 2 \mathrm{~h} \\
\text { Kurs proseminaryjny, } 2 \mathrm{~h}\end{array}$ \\
\hline $1935 / 1936$ & Jan Stanisławski & $\begin{array}{l}\text { Kurs dla początkujących, } 2 \mathrm{~h} \\
\text { Kurs dla zaawansowanych, } 2 \mathrm{~h} \\
\text { Kurs proseminaryjny, } 2 \mathrm{~h}\end{array}$ \\
\hline
\end{tabular}

${ }^{105}$ W 1926 r. Dziewicki odbył zajęcia tylko od października do grudnia.

${ }^{106}$ W roku akademickim 1927/1928 Dziewicki nie prowadził już zajęć. W marcu 1928 r. Senat UJ zatwierdził kandydaturę Greene'a. Zob. AUJ, WF II 191, k. 54.

${ }^{107}$ W II trymestrze roku akademickiego 1933/1934 W. Jezierski prowadził kurs „Basic English” Ogdena. 


\begin{tabular}{|l|l|l|}
\hline $1936 / 1937$ & Jan Stanisławski & $\begin{array}{l}\text { Język dla początkujących, 2 h } \\
\text { Język dla zaawansowanych, 2 h } \\
\text { Kurs proseminaryjny, 2 h }\end{array}$ \\
\hline $1937 / 1938$ & Jan Stanisławski & $\begin{array}{l}\text { Język dla początkujących, 2 h } \\
\text { Język dla zaawansowanych, 2 h } \\
\text { Kurs proseminaryjny, 2 h }\end{array}$ \\
\hline $1938 / 1939$ & Jan Stanisławski & $\begin{array}{l}\text { Język dla początkujących, 2 h } \\
\text { Język dla zaawansowanych, 2 h } \\
\text { Kurs proseminaryjny, 2 h }\end{array}$ \\
\hline
\end{tabular}

Źródło: Uniwersytet Jagielloński w Krakowie. Spis wykładów w pótroczu zimowem, rok szkolny 1918/19 1938/39, Kraków.

Jak wynika z zestawienia, przez cały okres międzywojenny UJ - podobnie jak USB - zatrudniał w każdym roku akademickim tylko jednego lektora języka angielskiego.

Dziewicki prowadził po sześć godzin zajęć w dwóch lub trzech grupach. Charakterystycznym dla niego kursem był przedmiot „Tłumaczenie i objaśnianie autorów klasycznych". Stanisławski również uczył angielskiego w trzech grupach, przy czym jedna z nich obejmowała zwykle studentów filologii angielskiej (,proseminarium”/ „kurs proseminaryjny”). Aż do 1939 roku liczba godzin lektorskich w każdym roku akademickim obejmowała sześć godzin tygodniowo.

Po odejściu na emeryturę Dziewickiego władze WH rozpoczęły poszukiwania nowego wykładowcy. Od 1 kwietnia 1928 roku zatrudniono na stanowisku lektora Godfreya Greene'a ${ }^{108}$.

\section{Michał Henryk Dziewicki}

Michał Seweryn Dziewicki (1851-1928) urodził się 21 marca 1851 roku w Bridgewater. Wychował się we wspólnocie kwakrów zwanej Religijnym Towarzystwem Przyjaciół. W 1863 roku jego cierpiący na depresję ojciec utopił się w rzece. W 1865 roku Michał skończył szkołę w Sibford, a w latach 1866-1872 pobierał nauki w gimnazjum w Polignan (Francja). W tym czasie przeszedł na katolicyzm, przybierając imię Henry (Henryk). W 1872 roku wstąpił do Towarzystwa Jezusowego i choć przygotowywał się do życia w zakonie jezuitów, z nieznanych przyczyn nie przyjął święceń zakonnych.

W 1881 roku przybył do Krakowa, podejmując pracę guwernera ${ }^{109}$. Niedługo potem poślubił Adelę Jastrzębską, znaną później z działalności dobroczynnej ${ }^{110}$.

108 AUJ, S II 619.

109 Jak wynika z podania do WF UJ z 7 VII 1883 r., udzielał lekcji angielskiego m.in. w domu książąt Lubomirskich. Zob. AUJ, WF II 191.

110 M. Estreicherówna, Dziewicka Adela z Jastrzębskich (1858-1927) [w:] PSB, t. 6, 1948, s. 170 . 
W 1883 roku Dziewicki wydał angielskie tłumaczenie Konrada Wallenroda. W tym samym roku złożył podanie o stanowisko lektora na UJ, ale próba zakończyła się niepowodzeniem ${ }^{111}$.

W 1888 roku wyjechał na dwa lata do Londynu ,w sprawie literackiej"112. Z inicjatywy angielskiego mediewisty Fredericka J. Furnivalla podjął się opracowania łacińskich rozpraw Johna Wyclefa ${ }^{113}$, wykorzystując swoje wykształcenie teologiczne ${ }^{114}$. Rozprawy wydało w Londynie towarzystwo Wycliffe Society, doceniając trud Dziewickiego $^{115}$.

W Archiwum Uniwersytetu Jagiellońskiego brak kolejnego podania Dziewickiego o zatrudnienie, ale 29 czerwca 1895 roku zebrała się komisja w sprawie lektoratu angielskiego. Jak wynika z protokołu, postanowiła ona wystąpić do ministerstwa o stanowisko lektora angielskiego w wymiarze dwóch godzin tygodniowo. Posadę tę zaproponowano Dziewickiemu, który 7 kwietnia 1896 roku został mianowany ,prowizorycznym lektorem języka angielskiego z roczną płacą 600 koron"116.

W piśmie Dziewickiego do Rady WF z 5 marca 1901 roku czytamy:

Mój sposób uczenia polegający na czytaniu głośno i rozmowie, skoro tylko uczniowie mogą w niej brać udział, okazał się bardzo skuteczny, ponieważ z końcem pierwszego kursu mogliśmy już rozmawiać, ja zaś wykładałem gramatykę w języku angielskim bez pomocy polskiego. Zaraz jednak na początku spostrzegłem, że elementarne lekcye byłyby dla wielu uczniów bezużyteczne z tej przyczyny, że już początki języka angielskiego posiadali. Z tego powodu zorganizowałem bezpłatny dopełniający kurs dyktatu, czytania i zadań, na który uczniowie więcej posunięci w języku angielskim uczęszczali ${ }^{117}$.

Reskryptem z 24 maja tego roku zwiększono liczbę godzin lektoratu do 6, podwyższając pobory do 1200 koron $^{118}$. Być może w celu zdobycia dodatkowych atutów Dziewicki zaczął pisać o sprawach polskich do anglojęzycznych pism: w 1902 roku ukazał się między innymi jego artykuł o Sienkiewiczu, a w 1904 roku - o ,życiu państwowym polskim"119. Wydał także Słowniczek-karzełek polsko-angielski

111 R. Dyboski, Dziewicki Michat Seweryn [w:] PSB, t. 6, 1948, s. 171. Jest to niejasny epizod, ponieważ reskryptem z 15 X 1883 r. Prezydium Namiestnictwa we Lwowie wyraziło zgodę na ,,przypuszczenie prywatnych nauczycieli języka i literatury angielskiej Michała Henryka Dziewickiego i Bolesława Ziołeckiego do wykładania na tamtejszym uniwersytecie języka i literatury angielskiej w charakterze lektorów”. Zob. AUJ, WF II 191.

112 AUJ, S II 619.

113 John Wyclef był angielskim reformatorem Kościoła z XIV w.

114 Zob. R. Dyboski, Dziewicki..., s. 171.

115 W liście z 20 X 1908 r. Furnivall pisał do Dyboskiego: „Fraternize with your friend Dziewicki [lector of English in the University] who helps us so well with our Wycliff Society". R. Dyboski, [Rozdział] IX [w:] Frederick James Furnivall: A Volume of Personal Record, ed. J.J. Munro, LondonNew York 1911, s. 42.

116 Pismo z Namiestnictwa we Lwowie do dziekanatu WF, AUJ, WF II 191.

117 WF II 191.

118 AUJ, S II 619, Wykaz służby.

119 R. Dyboski, Dziewicki..., s. 171. 
i angielsko-polski (1910) oraz A Reading Book for Beginners, Composed of Selected Fragments from Shakespeare (1914) ${ }^{120}$.

W latach 1913-1923 Dziewicki korespondował z Bertrandem Russellem, czołowym brytyjskim filozofem ${ }^{121}$. W 1914 roku zetknął się z Ludwigiem Wittgensteinem, kolejnym wybitnym myślicielem ${ }^{122}$. Wymiana myśli dotyczyła tez dzieła Tractatus logico-philosophicus.

W piśmie z 7 grudnia 1918 roku Dziekan WF zwrócił się do MWRiOP z prośbą o podwyższenie pensji lektora do 2400 koron, wyjaśniając, że Dziewicki zamierza wyjechać za granicę, bo z tak niskim uposażeniem „wyżyć nie może”. Wyjaśnia, że byłaby to wielka strata, ponieważ kwalifikacje Dziewickiego są znacznie wyższe od „przeciętnego poziomu lektora" 123 .

W tym czasie lektor był obciążony ogromną liczbą godzin dydaktycznych. Jak wynika z listu do Russella z 15 lutego 1920 roku $^{124}$, „,musi pracować dziennie prawie 11 godzin, a jedynie 3 dni w tygodniu 10 godzin”. Oprócz kursów na UJ Dziewicki miał zajęcia w szkole handlowej ${ }^{125}$ i lekcje prywatne ${ }^{126}$. Pod nieobecność Dyboskiego powierzono mu również wykłady dla studentów filologii angielskiej ${ }^{127}$. Co więcej, praca dydaktyczna nie była jego jedynym zajęciem. Już wcześniej przekładał na angielski dzieła literackie i publikacje członków Akademii Umiejętności w Krakowie ${ }^{128}$, ale tym razem podjął się tłumaczenia powieści: Kobiet Zofii Nałkowskiej (1920), a także Chłopów (1924-1925) i Ziemi obiecanej (1927) Władysława Reymonta ${ }^{129}$.

17 marca 1925 roku Dziewicki złożył wniosek o rezygnację ze stanowiska lekto$\mathrm{ra}^{130}$, ale pod wpływem oporu władz wrócił do pracy na kolejne dwa lata. W styczniu 1927 roku pogorszył się jego stan zdrowia ${ }^{131}$. W tej sytuacji Rada WF wystąpiła do

120 Dziewicki jest także autorem książeczki Legend of the Blessed Virgin Mary, Mother of Christ Our Lord (1882), powieści Entombed in Flesh (1898), a także wierszy drukowanych w angielskiej prasie (np. w piśmie „Family Herald”). Zob. podanie o stanowisko „profesora języka angielskiego” w UJ. AUJ, WF II 191.

121 J. Bremer, Michat Dziewicki - edytor, logik, lektor, thumacz, powieściopisarz, „Przegląd Filozoficzny - Nowa Seria" 2016, t. 3, z. 99, s. 214-218.

122 Idem, Ludwig Wittgenstein - Michat Dziewicki, czyli ,,genialny młody człowiek” spotyka ,mitego starszego pana” [w:] Ludwig Wittgenstein „przydzielony do Krakowa”, red. J. Bremer, J. Rothhaupt, Kraków 2009, s. 9.

${ }^{123}$ AUJ, WF II 191, k. 65. Dziewicki nie tylko zasłużył się dla kultury polskiej, ale także miał duże zasługi w dziedzinie propagandy politycznej. Zob. R. Dyboski, Dziewicki..., s. 171.

124 J. Bremer, Michat Dziewicki.., s. 219.

125 Pismo Dziekana WF do Prezydenta RP z 24 II 1927 r., AUJ, WF II 191.

126 Sytuacja materialna Dziewickich była trudna. Jak pisał Dziewicki do Russella: ,trudno bowiem kupować książki, kiedy $1 £=1000$ Koron”. Zob. J. Bremer, Michat Dziewicki..., s. 219.

127 Pismo z MWRiOP z 17 XI 1922 r. AUJ, S II 619.

128 Tłumaczył m.in. studium Bronisława Piłsudskiego poświęcone plemieniu Ajnów. J. Stasze1, Bronisław Piłsudski i jego zwiazki z Akademia Umiejętności w Krakowie, „Rocznik Biblioteki Naukowej PAU i PAN w Krakowie" 2001, t. 46, s. 7-104.

129 Reymont zabiegał o to, aby thumaczem jego powieści był Dziewicki. E.P. Kelly, A Venerable Polish Scholar, „Poland” 1926, t. 10, s. 627-628.

130 AUJ, S II 619.

131 Inicjatorem tego kroku był Dyboski, który - jak określa to pismo do Prezydenta RP z 24 II 1927 r. - „Z wdzięcznością zalicza się do jego uczniów”. Zob. AUJ, WF II 191. 
MWRiOP, w drodze łaski, o „pensję emerytalną""132. Niestety, Dziewicki cieszył się emeryturą zaledwie pół roku, ponieważ zmarł w Krakowie 10 lipca 1928 roku.

\section{Godfrey G.R. Greene}

Godfrey George Roundell Greene (1888-1958) urodził się 19 maja 1888 roku w Kensington w Londynie. W latach 1902-1907 był uczniem prestiżowej szkoły St. Peter's College w Westminsterze, a następnie wstąpił na Uniwersytet Oksfordzki, który ukończył z wyróżnieniem w 1912 roku, uzyskując licencjat (B.A.). Po studiach pracował nad słownikiem historycznym Oxford English Dictionary (1884-1928), ale pod koniec 1914 roku porzucił pracę, zaciągając się do wojskowych służb medycznych $^{133}$. Po wojnie wrócił do Oksfordu, aby kontynuować studia i w 1920 roku otrzymał stopień magistra (M.A.).

W latach 1920-1927 Greene był lektorem angielskiego na Uniwersytecie w Göteborgu (Szwecja). W 1928 roku przyjechał do Krakowa, gdzie zatrudniono go na stanowisku lektora angielskiego od 1 kwietnia ${ }^{134}$. MWRiOP zaakceptowało jego kandydaturę i pismem z 19 czerwca 1928 roku przyznało mu wynagrodzenie za sześć godzin wykładów tygodniowo ${ }^{135}$. Po zakończeniu kursów Greene wyjechał do Londynu, a we wrześniu 1928 roku znalazł zatrudnienie na Uniwersytecie w Helsin$\mathrm{kach}^{136}$, gdzie pracował do 1946 roku.

W 1955 roku przekazał bibliotece szkoły w Westminsterze swój księgozbiór ${ }^{137}$ obejmujący wydania dzieł takich znaczących brytyjskich autorów jak Richard Hakluyt, John Locke i John Dryden ${ }^{138}$. Zmarł w Ploughley w 1956 roku.

\section{Jan Stanisławski}

Jan Stanisławski (1893-1973) urodził się 20 kwietnia 1893 roku w Tomsku na Syberii. Był synem Artura Stanisławskiego, inżyniera-górnika i publicysty, oraz Emilii (z domu Bujard), nauczycielki francuskiego.

W 1900 roku Jan został wysłany do Francji, gdzie rozpoczął naukę w szkole katolickiej prowadzonej przez Towarzystwo św. Edmunda. Wskutek dekretu

${ }_{132}$ W piśmie z 20 I 1928 r. MWRiOP informuje UJ, że Dziewickiemu przyznano zaopatrzenie emerytalne. AUJ, WF II 191.

133 P. Gilliver, The Making of the Oxford English Dictionary, Oxford 2016, s. 325.

134 AUJ, WF II 191.

135 W liście do Rektoratu UJ Greene skarży się, że wciąż nie otrzymał poborów za prowadzenie zajęć (AUJ, S II 619). Należne mu wynagrodzenie wypłacono 22 VI 1928 r.

136 Radę WF poinformował o tym fakcie Dyboski w liście z 27 VI 1928 r. AUJ, S II 619.

137 „The Elizabethan” 1955, t. 26, z. 11, nr 611, s. 141.

138 Directory of Rare Book and Special Collections in the United Kingdom and Republic of Ireland, ed. K. Attar, London 2016, s. 277. 
o sekularyzacji szkolnictwa francuskiego w 1901 roku szkołę ,przeniesiono” do Anglii1 ${ }^{139}$. Stanisławski skończył St. Michael's College w Hitchin ${ }^{140}$ w 1910 roku $^{141}$, po czym wyjechał do Francji, aby podjąć studia ${ }^{142}$. Jednocześnie otrzymał posadę urzędnika w banku. Po wybuchu I wojny światowej powrócił do Rosji ${ }^{143}$. Jako szeregowiec walczył w armii rosyjskiej do 1917 roku, a po demobilizacji osiadł w Tomsku.

Po odzyskaniu przez Polskę niepodległości Stanisławski przybył do Krakowa. W 1920 roku zaciągnął się do Wojska Polskiego i z pewnością brał udział w wojnie polsko-bolszewickiej ${ }^{144}$. W 1921 roku ukończył Szkołę Podchorążych w Bydgoszczy, uzyskując stopień podporucznika. Po krótkim okresie służby przeszedł do rezerwy. Wrócił do Krakowa, gdzie w 1922 roku rozpoczął pracę w Banku Związku Spółek Zarobkowych i w tym samym roku ożenił się z Marią Pizło. W 1923 roku urodziła się im córka Małgorzata (zamężna Szercha) ${ }^{145}$.

W 1924 roku Stanisławski objął stanowisko wicedyrektora w krakowskim oddziale YMCA ${ }^{146}$. Kilka wykładów poprowadził tam Roman Dyboski ${ }^{147}$, co pozwoliło na nawiązanie kontaktów między Stanisławskim i Dyboskim. W 1927 roku Stanisławski zaczął prowadzić kurs angielskiego nadawany przez krakowską rozgłośnię Polskiego Radia ${ }^{148}$.

Po wyjeździe Greene'a z Krakowa w czerwcu 1928 roku Dyboski zaproponował na stanowisko lektora Stanisławskiego, który „włada [...] angielskim doskonale w mowie i na piśmie. Będąc od kilku lat czynnym jako nauczyciel języka angielskiego w Krakowie, zyskał sobie powszechne uznanie zarówno ze względu na skuteczność i celowość stosowanych metod, jak i na sumienność i obowiązkowość". Ważne było także i to, że - jak pisze Dyboski - ,ze wspólnej pracy społecznej jest mi

139 Zob. P. Mroczkowski, M. Szercha, Jan Stanisławski 20 IV 1893-4 VII 1973 [w:] Kronika Uniwersytetu Jagiellońskiego za lata akademickie 1972/1973-1974/1975, Kraków 1980, s. 106.

140 Stanisławski miał rozpocząć szkołę w Hitchin w 1901 r., ale jest to mało prawdopodobne, ponieważ powstała ona dopiero w 1903 lub 1904 r. Zob. W. Baczkows ka, Jan Stanistawski (1893-1973) [w:] Wyrok na Uniwersytet Jagielloński 6 listopada 1939 roku, red. L. Hajdukiewicz, Kraków 1989, s. 224-225; R. Hine, The Story of Hitchin, t. 2. London 1972, s. 433.

${ }_{141}$ W podaniu o pracę lektora na UJ z 8 VI 1928 r. podaje: ,jestem absolwentem klasycznej szkoły angielskiej St. Michael's College w Hitchin (Herts), gdzie równocześnie odbyłem studia humanistyczne z zakresu angielskiej szkoły średniej i francuskiego 'baccalauréat"”. AUJ, S II 619.

142 P. Mroczkowski, M. Szercha, Jan Stanistawski.., s. 106; J. Podhorodecka, Stanistawski Jan (1893-1973) [w:] PSB, t. 42, 2003, z. 1, s. 119.

143 Wynika to z jego życiorysu z 23 I 1950 r. AUJ, S II 619.

144 Na ten temat nie ma żadnej informacji, ale jest niemożliwe, aby jako wojskowy nie brał udziału w walkach.

145 Będąc absolwentką studiów polonistycznych na UJ, pracowała jako asystentka ojca i tłumaczka.

146 T. Pudłocki, op. cit., s. 191. Ze wspomnień Rose’a wiemy, że jego współpracownik w YMCA, Amerykanin E.O. Jacobs, miał „pierwszorzędnego asystenta” [M.P.], dzięki któremu Rose nie był już potrzebny w Krakowie. The Polish Memoirs of William John Rose, ed. D. Stone, Toronto 1975, s. 172.

147 The Polish Memoirs..., s. 156.

148 M.J. Kwiatkowski, Narodziny polskiego radia. Radiofonia w Polsce w latach 1918-1929, Warszawa 1972, s. 219. 
znany jako człowiek o nieposzlakowanym charakterze i prawdziwie obywatelskim duchu"149.

Stanisławski został zatrudniony na podstawie corocznie odnawianej umowy ${ }^{150}$. Do jego obowiązków należało prowadzenie dwóch kursów tygodniowo dla słuchaczy wszystkich fakultetów i jednego dwugodzinnego kursu dla studentów anglistyki. Uczył angielskiego także w Wyższym Studium Handlowym. Oprócz tego opracowywał podręczniki: First Steps in English (1928), A Pole's Trip to London (1929) i A Pole in London (1939). W 1933 roku ukazał się pierwszy słownik - Słowniczek angielsko-polski i polsko-angielski (1933) ${ }^{151}$.

Jako oficer rezerwy Stanisławski uczestniczył w kampanii wrześniowej w 20. Pułku Piechoty. Pod Zamościem dostał się do niewoli niemieckiej, ale zbiegł z transportu kolejowego. W listopadzie 1939 roku aresztowano go wraz z grupą profesorów UJ i wywieziono do obozu koncentracyjnego w Sachsenhausen. Po zwolnieniu 8 lutego 1940 roku utrzymywał się z prywatnych lekcji języków obcych. Od 1942 roku pracował także w Niemieckiej Szkole Administracji. Pisał o tym tak:

W r. 1941 zaproszono mnie do nauczania języka angielskiego w niemieckiej szkole, Verwaltungsschule, przy czym niedwuznacznie dano mi do zrozumienia, że odmowa mogłaby pociągnąć za sobą represje. Częściowo z powodu możliwości tych represji, które postawiłyby moją rodzinę w krytycznym położeniu, a częściowo z uwagi na wzrastającą trudność utrzymania się na wolności i zachowania posiadanego mieszkania [...] przyjąłem rzeczone zaproszenie, na co zresztą udzielił mi swej aprobaty p. prof. W. Szafer ${ }^{152}$.

W latach 1943-1944 w ramach tajnego nauczania prowadził zajęcia $\mathrm{z}$ fonetyki i gramatyki opisowej dla studentów $\mathrm{UJ}^{153}$.

Po wojnie Stanisławski prowadził kursy angielskiego na UJ, w Akademii Handlowej i Akademii Medycznej. Wydał kolejne prace: A New English Manual (1945), Nowy słownik angielsko-polski i polsko-angielski (1945), English Correspondence and Commercial English (1946) oraz Gramatyke angielska dla zaawansowanych (1950-1951). Przez wiele lat był „kontraktowym adiunktem-lektorem języka angielskiego na Wydziale Humanistycznym" ${ }^{154}$. UJ zaproponował mu umowę na czas ,nieoznaczony" dopiero 15 października 1952 roku ${ }^{155}$.

Stanisławski był wytrawnym metodykiem. Nic dziwnego, że w opinii z 12 grudnia 1955 roku Vilim Frančić, zastępca kierownika SJO UJ, wyrażał się o nim bardzo

149 AUJ, S II 619.

150 AUJ, S II 619, arkusz personalny.

151 Ten sam słownik wydała w 1929 r. Księgarnia Wysyłkowa G. Dorn.

152 Relacje pracowników Uniwersytetu Jagiellońskiego o ich losach osobistych i dziejach uczelni w czasie drugiej wojny światowej, red. J. Michalewicz, Kraków 2005, s. 364.

${ }^{153}$ C. Grece-Dą brow ska, English Literature in the Secret University of Cracow [w:] Ne cedat Academia. Kartki z dziejów tajnego nauczania w Uniwersytecie Jagiellońskim 1939-1945, red. M. i A. Zarębowie, Kraków 1975, s. 181-183.

154 AUJ, S II 619.

155 W tym samym roku otrzymał nagrodę Rektora UJ za doskonałe wyniki pracy dydaktycznej. Informację tę podaje dr Vilim Frančić, kierownik Studium Języków Obcych (dalej: SJO) UJ, w opinii z 12 XII 1955 r. (S II 619). 
pozytywnie ${ }^{156}$. Podobną opinię miała Krystyna Michalik ${ }^{157}$, która w 1957 roku proponowała odznaczenie Stanisławskiego Krzyżem Kawalerskim Orderu Polonia Restituta $^{158}$.

W 1955 roku, na trzy lata przed emeryturą, Stanisławski podjął się opracowania Wielkiego stownika angielsko-polskiego i polsko-angielskiego (1964-1969) ${ }^{159}$, za który otrzymał odznakę Zasłużonego Działacza Kultury. Zmarł w Krakowie 4 sierpnia 1973 roku.

\section{PODSUMOWANIE}

W okresie międzywojennym USB i UJ nie opracowywały programów nauczania języków obcych. W toku studiów określało się poziom zajęć, ale szczegółowy zakres tematyczny oraz sposoby, w jaki osiągnięty miał zostać zamierzony cel dydaktyczny, zależały wyłącznie od inwencji lektora. Można sądzić, że każdy z nich polegał w tym względzie na własnej intuicji i doświadczeniu.

Jak wynika z biogramu Gruzińskiej, była ona kobietą o niezwykłej inteligencji. Mimo że należała do arystokracji, przez kilkanaście lat pracowała jako nauczycielka w szkołach w Rosji, Polsce i na Łotwie. Swoje życie poświęciła szerzeniu idei katolickiej, niejako przy okazji zajmując się nauką języków. Studnicka była, jak na owe czasy, kobietą wyjątkowo samodzielną ${ }^{160}$. Studiowała na najlepszych europejskich uczelniach, ale nie zdołała uzyskać doktoratu, który mógłby pomóc w umocnieniu jej pozycji. Małżeństwo, dziecko, przeprowadzki i kłopoty męża, wynikające z jego temperamentu politycznego oraz proniemieckiej orientacji, musiały wywrzeć negatywny wpływ na rozwój jej kariery.

Silną osobowość miała również Grabińska; choć jej ambicje naukowe skończyły się wraz ze zrobieniem doktoratu, posiadała niewątpliwy potencjał intelektualny, którego nie wykorzystała w pełni. Dużą rolę odegrały tu jej obowiązki rodzinne, w tym rola żony dyplomaty. Talentu, zdecydowania i woli działania nie można odmówić także Kospothowi-Pawłowskiemu. Miał wszelkie predyspozycje, aby stać się autorem kolejnych materiałów dydaktycznych do nauki angielskiego, ale szansę przekreśliły dramatyczne losy wojenne.

Jeśli chodzi o lektorów krakowskich - z pominięciem Greene'a, którego związek z UJ był krótki - zarówno Dziewicki, jak i Stanisławski zaliczali się do osób

156 Osiągnięć Stanisławskiego nie zauważyła Iwan. Zob. K. Iwan, Nauczanie języków obcych nowożytnych w Polsce w latach 1919-1939. Koncepcje organizacyjno-programowe, Poznań 1972, s. 4.

157 Krystyna Michalik skończyła filologię angielską i germańską na UJ, doktoryzowała się u Dyboskiego w 1935 r., a po wojnie pracowała w SJO UJ. Zob. Z. Mazur, op. cit., s. 10.

158 AUJ, S II 619.

159 Redakcji słownika podjął się polski fonetyk Wiktor Jassem, a wydawcą było wydawnictwo Wiedza Powszechna. Stanisławski był również współautorem mniejszych słowników, przygotowanych we współpracy z Katarzyną Billip, Zofią Chociłowską, Janiną Jaślan i Małgorzatą Szerchą.

160 Zob. także K. Studnicki-Gizbert, op. cit., s. 26. 
niewiarygodnie pracowitych. O ile jednak Dziewicki poświęcał wiele czasu zainteresowaniom scholastycznym i filozoficznym, o tyle Stanisławski twardo stąpał po ziemi. Jak wynika z korespondencji z Marianem Kisterem ${ }^{161}$, wydawał się też zaradniejszy niż jego poprzednik. W obu przypadkach motywem pchającym ich do pracy była pasja, ale pewien wpływ musiała również wywrzeć chęć wykazania się osiągnięciami wobec niebezpieczeństwa utraty pracy.

\section{BIBLIOGRAFIA}

\section{Źródła archiwalne}

Archives and Research Collections of McMaster University, Hamilton, Ontario

C.K. Ogden fonds (box 87, f. 14), correspondence of Ogden, C.K. [and Leonora W. Lockhart] and Kospoth-Pawlowski, W. (1933-1935).

Archiwum Akt Nowych w Warszawie

Zesp. 252, Polska Spółka Drzewna CENTURY. Anglo-Europejskie Towarzystwo Akcyjne. Zastępstwo na Polskę, 1924-1931, 1935.

Archiwum Instytutu Polskiego i Muzeum im. gen. Sikorskiego w Londynie

Materiały archiwalne A44.123/10, k. 387-388, k. 395-401.

Archiwum Nauki PAN i PAU w Krakowie

Spuścizna Romana Dyboskiego, sygn. K III-90 (w opracowaniu).

Archiwum Uniwersytetu Jagiellońskiego w Krakowie

S II 308a, Studentki, słuchaczki zwyczajne.

S II 619, Dziewicki Michał; S II 619, Greene Godfrey; S II 619, Stanisławski Jan.

WF II 191, Lektoraty języków obcych, lektorat angielski.

WF II 504, Teczki akt doktorskich, podania o dopuszczenie do egzaminów ścisłych, ocena pracy, załączniki 1860-1945, Wanda Januszkiewiczówna.

Centralne Archiwum Wojskowe w Warszawie

Sygn. AP 1518, Kospot-Pawłowski Władysław.

Sygn. VIII.809.67 [akta NKWD], Kospat-Pawłowski Władysław.

Józef Piłsudski Institute of America w Nowym Jorku

W. Studnicki papers, fond 96, folder 1, dokumenty dotyczące Władysława i Aliny Studnickich.

161 Marian Kister był właścicielem oficyny wydawniczej Roy w Stanach Zjednoczonych. Zbiory Tomasza Niewodniczańskiego [dalej: ZTN] obejmują fragment archiwum spółki, w tym korespondencję Stanisławskiego z Kisterem w sprawie rekompensaty za przedruk słownika w Ameryce w okresie II wojny światowej. Jak wynika z pokwitowania z 10 VII 1946 r., Kister zapłacił Stanisławskiemu ogromną w owym czasie sumę 625000 złotych. ZTN, Warszawa, Zamek Królewski, zesp. 82, cz. 1, k. 445. 
Lietuvos Centrinis Valstybės Archyvas w Wilnie

Zesp. 175, 1 I Bb 596, Gruzińska Anastazja.

Zesp. 175, 1 I Bb 598, Januszkiewiczówna Wanda.

Zesp. 175, 1 I Bb 608, Studnicka z Brylińskich Alina.

Zesp. 175, 1 I Bb 691, Kospoth-Pawłowski Władysław.

Zesp. 175, 5 IV B 41, wykłady zlecone i lektoraty 1922/23-1926/27.

Zesp. 175, 5 IV B 190, wykłady zlecone i lektoraty 1930/31-1932/33.

Zesp. 175, 5 IV B 223, wykłady zlecone i lektoraty 1933/34-1935/36.

Zesp. 175, 1 I Ba 43, ogólne sprawy lektorskie, 1921/22-1936/37.

University of St. Andrews Archives

Records A/23, Minutes of the Court of the University of St. Andrews, 1915-20.

Zbiory Tomasza Niewodniczańskiego w Warszawie

Fragment archiwum Spółki Wydawniczej Rój (Roy) w Nowym Jorku, zesp. 82, cz. 1, Stanisławski Jan 1946-1948, k. 438-462.

\section{Źródła drukowane}

Catalogue des étudiants de l'Université de Lausanne. Année universitaire 1906-1910, https:// uniris.unil.ch/pandore/notice/catalogues-etudiants-unil/ [dostęp: 18.02.2018].

Program wyktadów i sktad uniwersytetu w pótroczu zimowem roku akademickiego 1919/20, Wilno 1919.

Spis wykładów i sktad uniwersytetu w roku akademickim 1920/21-1938/39, Wilno.

Sprawozdanie dyrekcji gimnazjum oo. Jezuitów w Wilnie... za rok szkolny 1927/28, Wilno 1928.

Uniwersytet Jagielloński w Krakowie. Spis wykładów w pótroczu zimowem, rok szkolny 1918/19-1938/39, Kraków.

Ustawa o szkołach akademickich z dnia 13 lipca 1920 roku, http://dziennikustaw.gov.pl/ du/1920/s/72/494 [dostęp: 18.02.2018].

Wolna Wszechnica Polska. Sprawozdanie z działalności w roku akademickim 1925/26, Warszawa 1926.

\section{Prasa}

„The Aberdeen Daily Journal” 1918

„The Elizabethan” 1955

„Evening Telegraph and Post” 1917

„Kurier Warszawski” 1928

\section{Opracowania}

Auty P., William J. Rose, „The Slavonic and East European Review” 1969, t. 47, z. 100, s. $8-10$.

Baczkowska W., Jan Stanistawski (1893-1973) [w:] Wyrok na Uniwersytet Jagielloński 6 listopada 1939 roku, red. L. Hajdukiewicz, Kraków 1989, s. 224-225. 
Barycz H., Wspomnienie o ks. Stanisławie Bednarskim, „Pamiętnik Literacki” 1946, t. 36, z. 1/2, s. 9-20.

Bremer J., Ludwig Wittgenstein - Michat Dziewicki, czyli , genialny młody człowiek” spotyka ,,milego starszego pana” [w:] Ludwig Wittgenstein „przydzielony do Krakowa”, red. J. Bremer, J. Rothhaupt, Kraków 2008, s. 13-20.

Bremer J., Michał Dziewicki - edytor, logik, lektor, tłumacz, powieściopisarz, „Przegląd Filozoficzny - Nowa Seria” 2016, t. 3, z. 99, s. 209-226.

Brylińska A., Smith P., Russian Fairy Tales, an Accented Russian Reader with Notes and Vocabulary, London 1919.

Directory of Rare Book and Special Collections in the United Kingdom and Republic of Ireland, ed. K. Attar, London 2016.

Durejko A., Polskie życie kulturalne i literackie na Łotwie w XX w., Wrocław 2001.

Dybiec J., Uniwersytet Jagielloński w latach 1918-1939, Kraków 2000.

Dyboski R., [Rozdział] IX [w:] Frederick James Furnivall: A Volume of Personal Record, ed. J.J. Munro, London-New York 1911, s. 38-43.

Dyboski R., Dziewicki Michat Seweryn [w:] Polski Słownik Biograficzny, t. 6, 1948, s. 171172.

Dzieje Uniwersytetu Warszawskiego 1915-1945, red. P.M. Majewski, Warszawa 2016.

Dzienniki: 1930-1936, red. B. Żongołłowicz, D. Zamojska, Warszawa 2004.

Estreicherówna M., Dziewicka Adela z Jastrzębskich (1858-1927) [w:] Polski Słownik Biograficzny, t. 6, 1948, s. 170.

Figura M., Rosja w myśli politycznej Władysława Studnickiego, Poznań 2008.

Gilliver P., The Making of the Oxford English Dictionary, Oxford 2016.

Gippius Z., Łaskowaja kobra. Swoja i Boż'ja, Moskwa 2015.

Grabińska W., Let Us Try. Podręcznik języka angielskiego. 1. rok nauczania, Katowice 1946.

Grabiński M., Dyplomacja w Dachau..., Łowicz 2007.

Grece-Dąbrowska, C., English Literature in the Secret University of Cracow [w:] Ne cedat Academia. Kartki $z$ dziejów tajnego nauczania $w$ Uniwersytecie Jagiellońskim 1939-1945, red. M. i A. Zarębowie, Kraków 1975, s. 181-183.

Hine R.L., The Story of Hitchin, t. 2, London 1972.

Iwan K., Nauczanie języków obcych nowożytnych w Polsce w latach 1919-1939. Koncepcje organizacyjno-programowe, Poznań 1972.

Kelly E.P., A Venerable Polish Scholar, „Poland” 1926, t. 10, s. 627-628.

Kospoth-Pawłowski W., Basic News: British, American, Scientific, International Commercial, nr 1-6, Wilno 1932-1934.

Kospoth-Pawłowski W., England and the English. Podręcznik do nauki języka angielskiego $w$ szkołach średnich ogólnokształcacych $i$ handlowych, cz. 1, Wilno 1930.

Kospoth-Pawłowski, W., Odwrót. Fragmenty [w:] Na szlaku Batorego, Księga zbiorowa oficerów rezerwy, Wilno 1926, s. 76-80.

Kospoth-Pawłowski W., Stownik angielsko-polski. Wstępny słowniczek do Basic English na podstawie "The Basic Words" C.K. Ogdena z krótka gramatyka, Wilno 1933.

Kucharski W.S., [Biogram M. Grabińskiego] [w:] M. Grabiński, Dyplomacja w Dachau..., Łowicz 2007.

Kwiatkowski M.J., Narodziny polskiego radia. Radiofonia w Polsce w latach 1918-1929, Warszawa 1972.

Mazur Z., Sto lat Instytutu Filologii Angielskiej Uniwersytetu Jagiellońskiego, Kraków 2011. 
Mroczkowski P., Historia Katedry Filologii Angielskiej w Uniwersytecie Jagiellońskim [w:] Wydziat Filologiczny Uniwersytetu Jagiellońskiego. Historia katedr, red. W. Taszycki, A. Zaręba, Kraków 1964, s. 337-347.

Mroczkowski P., Szercha M., Jan Stanisławski 20 IV 1893-4 VII 1973 [w:] Kronika Uniwersytetu Jagiellońskiego za lata akademickie 1972/1973-1974/1975, Kraków 1980, s. 106-107.

Nezabytyje mogity. Rossijskoe zarubeż'e: nekrołogi 1917-1999, t. 2: G-Z, Moskwa, red. E.W. Makarewicz, 1999, https://pomnirod.ru/materialy-k-statyam/захоронения/ люксенбург/незабытые-могилы-российское зарубежье-некрологи-1917-2001-г.г/ незабытые-могилы.-российское-зарубежье-некрологи-1917-1997.-том-2.-г-3.-1999. html [dostęp: 20.09.2017].

Olejnik, S.T., Wstęp [w:] M. Grabiński, Wieluń na przełomie wieków, Wieluń 2009, s. 7-23.

Piersa H., Staszewski Wacław (1892-1970) [w:] Polski Stownik Biograficzny, t. 42, 2004, z. 4, s. 536-537.

Podhajecka M., A History of Polish-English / English-Polish Bilingual Lexicography (1788-1947), Opole 2016.

Podhorecka J., Stanistawski Jan (1893-1973) [w:] Polski Stownik Biograficzny, t. 42, 2003, z. 1, s. 119-120.

The Polish Memoirs of William John Rose, ed. D. Stone, Toronto 1975.

Pudłocki T., Ambasadorzy idei. Wkład intelektualistów w promowanie pozytywnego wizerunku Polski w Wielkiej Brytanii w latach 1918-1939, Kraków 2015.

Relacje pracowników Uniwersytetu Jagiellońskiego o ich losach osobistych i dziejach uczelni w czasie drugiej wojny światowej, red. J. Michalewicz, Kraków 2005.

Stanisławski J., English Correspondence and Commercial English, Kraków 1946.

Stanisławski J., First Steps in English, [Warszawa] 1928.

Stanisławski J., Gramatyka angielska dla zaawansowanych. Szczegółowa analiza rozbiezności zachodzacych między gramatyka angielska a polska, t. 1, Warszawa 1950.

Stanisławski J., A New English Manual, Kraków 1945.

Stanisławski J., A Pole in London, Kraków 1939.

Stanisławski J., A Pole's Trip to London, Warszawa 1928.

Stanisławski J., Stowniczek angielsko-polski i polsko-angielski, Trebicz 1933.

Stanisławski J., Wielki stownik angielsko-polski, t. 1; Wielki słownik polsko-angielski, t. 2, red. W. Jassem, Warszawa 1964-1969.

Staszel J., Bronisław Pitsudski i jego związki z Akademią Umiejętności w Krakowie, „Rocznik Biblioteki Naukowej PAU i PAN w Krakowie" 2001, t. 46, s. 7-104.

Studnicki-Gizbert K., Moje wspomnienia z życia, które miałem, zdarzeń, które widziatem, i nauk, które otrzymałem, Chelsea 2016.

Szmidt J., Biblioteki polskie we wspótczesnym Londynie, Warszawa 1998.

Szubtarski G., Antykościelne ustawodawstwo w ZSRR za rządów Włodzimierza Lenina (1917-1923), „Kościół i Prawo” 2013, t. 2, z. 15, s. 63-75.

Świrski I., Słowo wstępne [w:] A. Gruzińska, Moje nawrócenie, Poznań 1933.

Tribunskij P.A., Alina Brylinskaja (Brilinskaja) i rossiewedenie w Welikobritanii, „Klio” 2016, t. 8, z. 116, s. 108-112.

Ulińska A., Państwowe Liceum im. Jana i Jędrzeja Śniadeckich w Wilnie (1938-1939), Białystok 1996. 


\section{ANEKS}

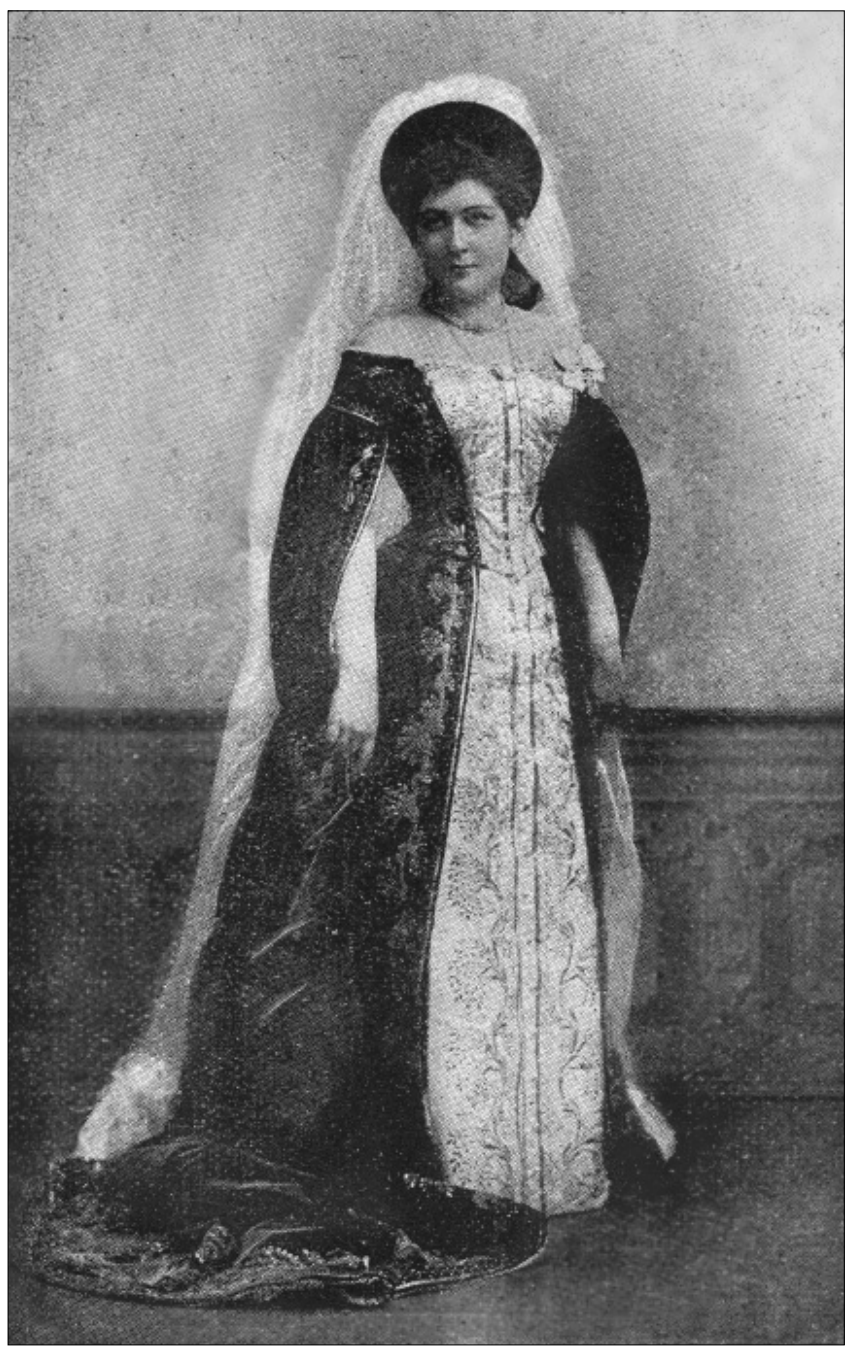

Księżniczka Anastazja Nikołajewna Gruzińska Fot. z książki Moje nawrócenie (1934) 


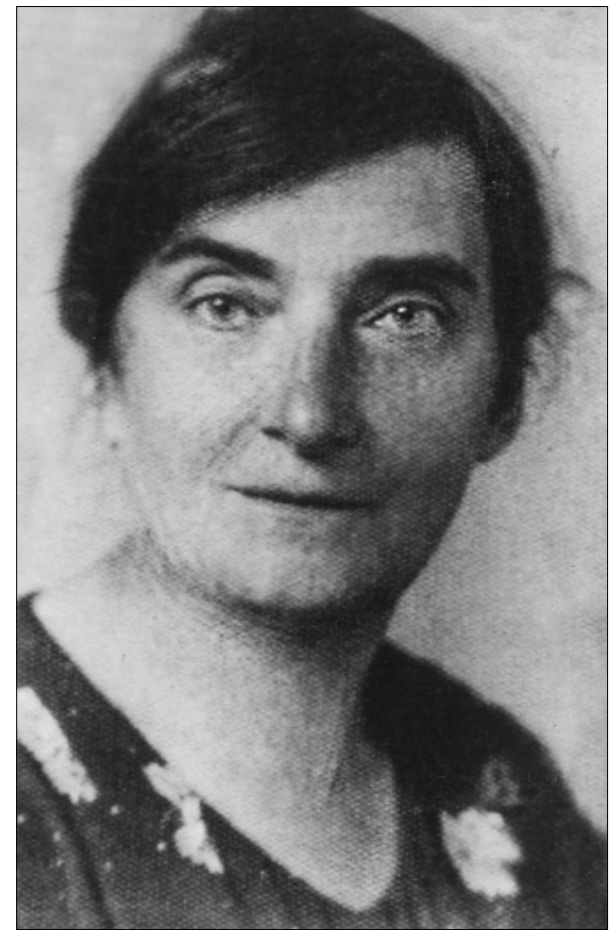

\author{
Alina Studnicka (Brylińska)
}

Zbiory prywatne Konrada Studnickiego-Gizberta

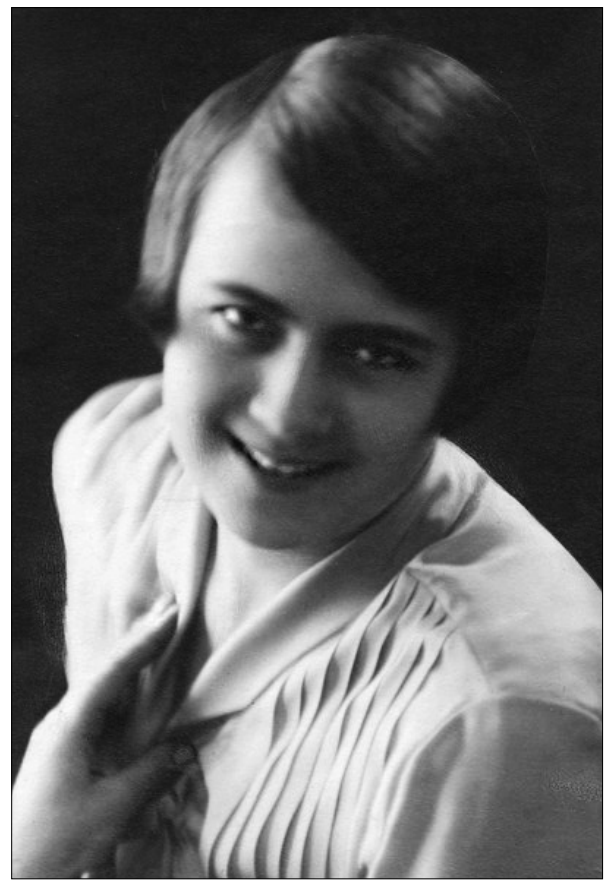

Wanda Januszkiewiczówna (Grabińska) Fot. Archiwum Polskiej Akademii

Umiejętności w Krakowie (www.pauart.pl/app/ artwork?id=AN_KIII_155_1000) 


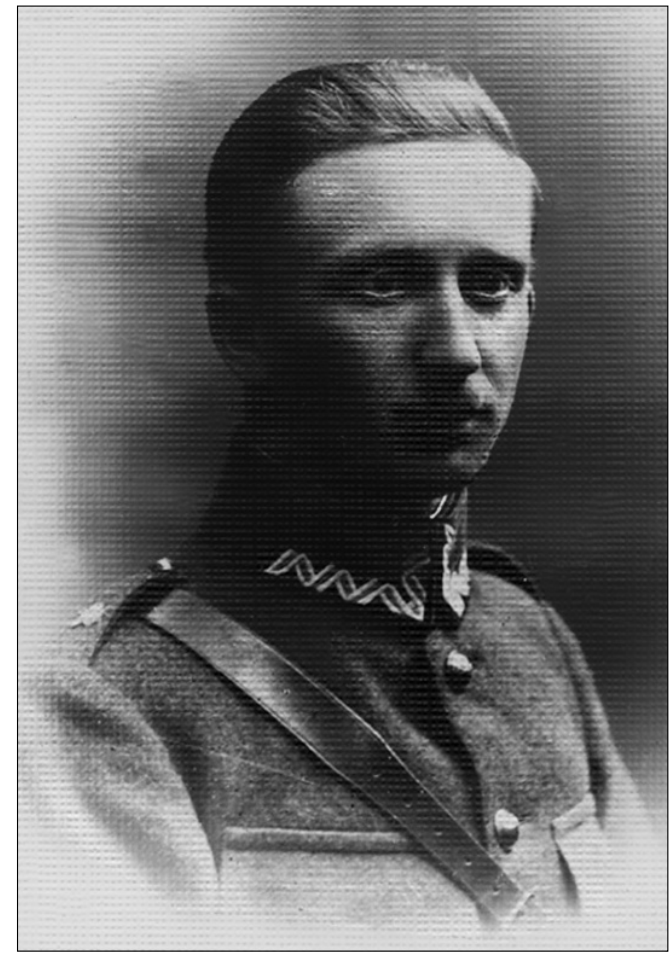

Władysław Kospoth-Pawłowski w mundurze podoficerskim Fot. CAW WBH, sygn. AP 1518

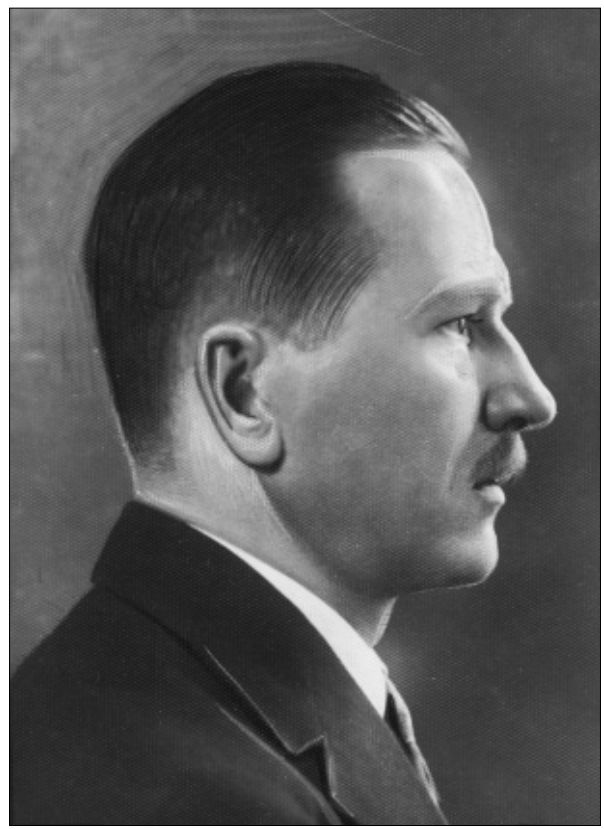
(https://audiovis.nac.gov.pl/) 


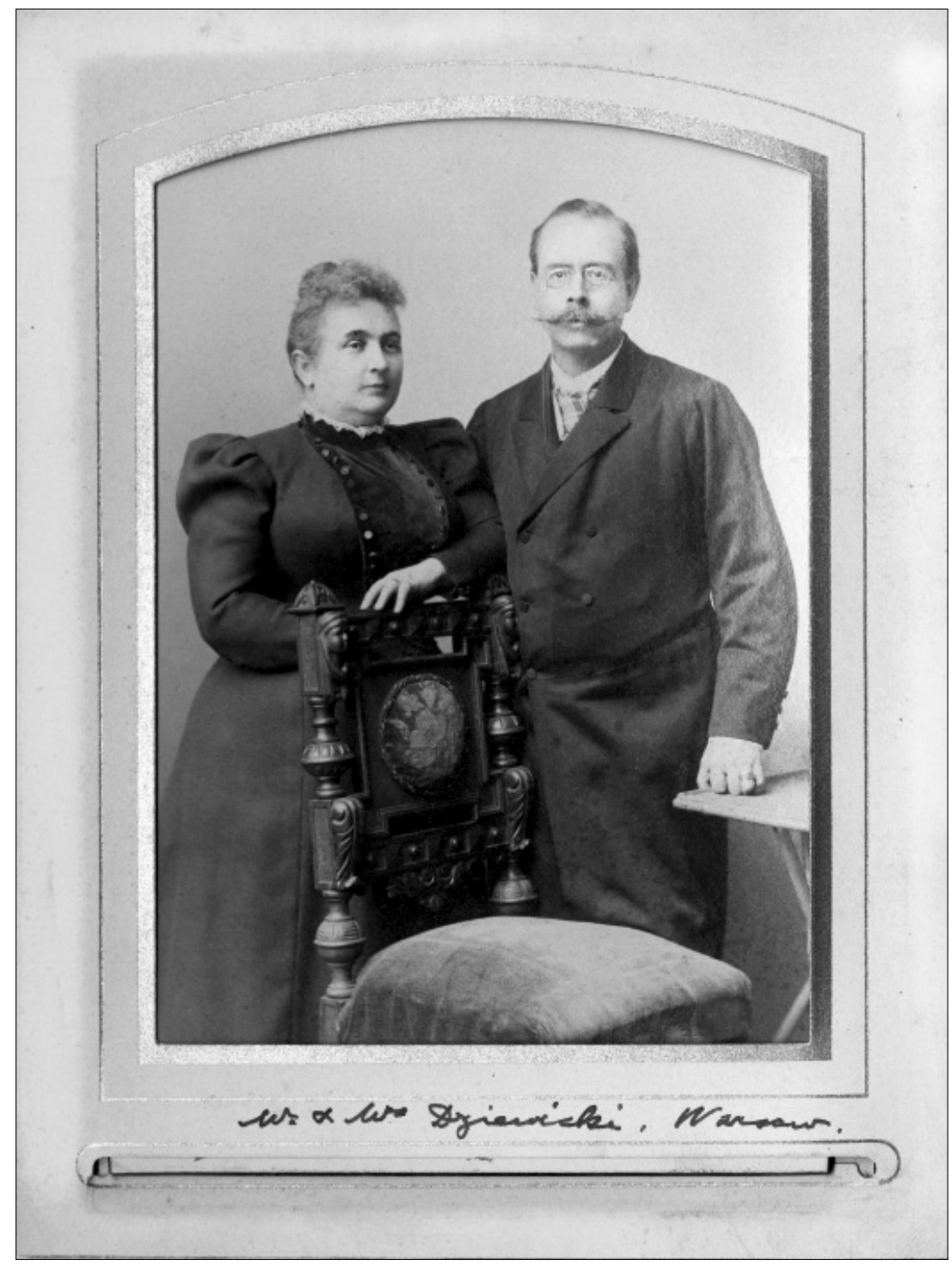

Michał Henryk Dziewicki i jego żona Adela z Jastrzębskich

Fot. z zasobów King's College

London Archives, sygn. FURNIVALL: 1/7/4 1895-[1901] 


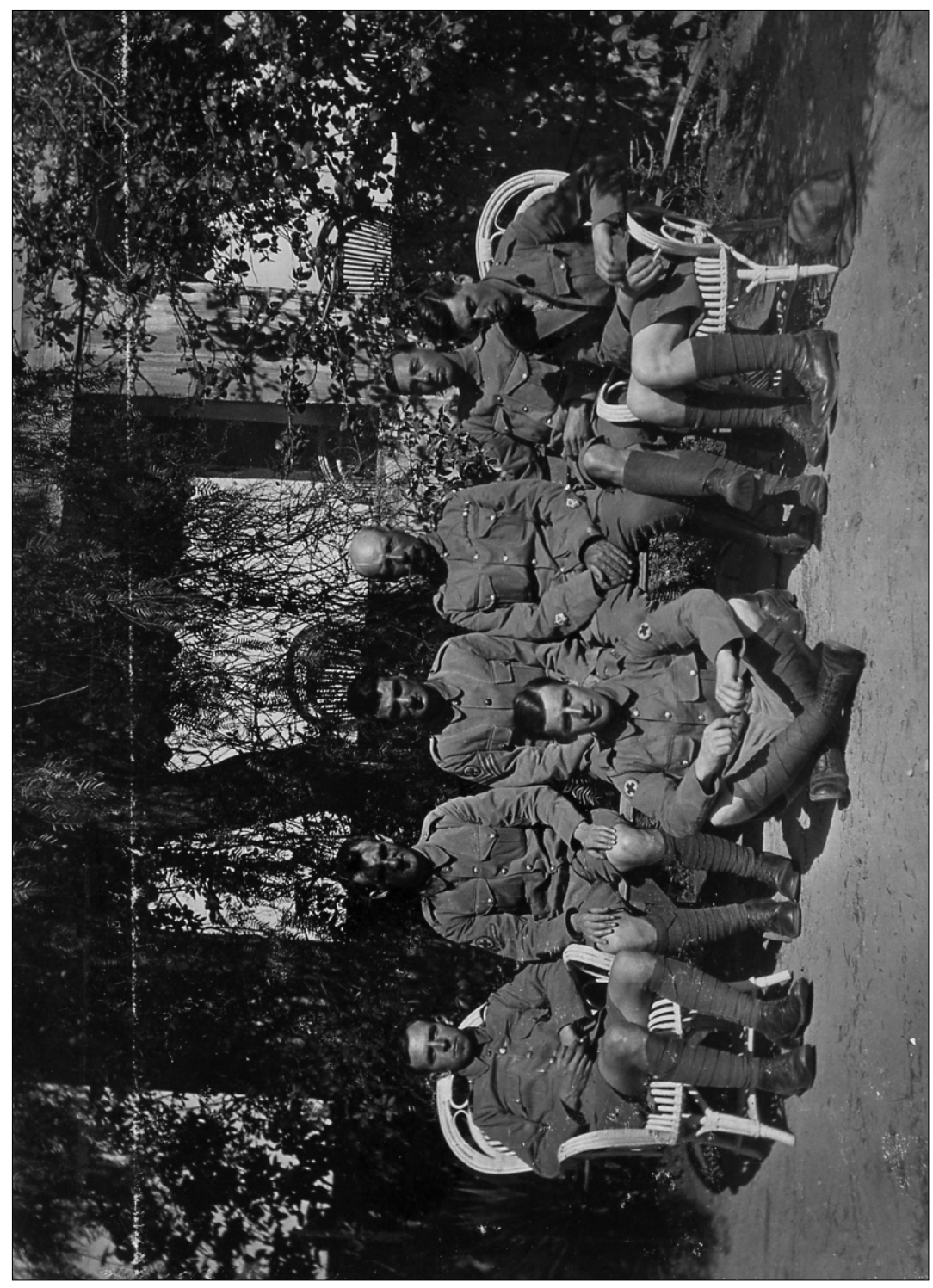

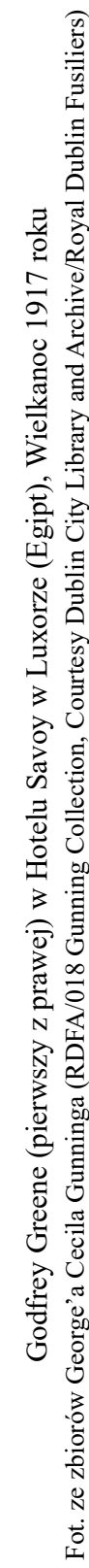

